\title{
Nitrate uptake and carbon exudation - do plant roots stimulate or inhibit denitrification?
}

\author{
Pauline Sophie Rummel 1 - Reinhard Well • Birgit \\ Pfeiffer • Klaus Dittert • Sebastian Floßmann • \\ Johanna Pausch
}

Received: 12 May 2020 / Revised: 25 September 2020 / Accepted: 20 October 2020 / Published online: 6 November 2020

(C) The Author(s) 2020

\begin{abstract}
Background and aims Plant growth affects soil moisture, mineral $\mathrm{N}$ and organic $\mathrm{C}$ availability in soil, all of which influence denitrification. With increasing plant growth, root exudation may stimulate denitrification, while $\mathrm{N}$ uptake restricts nitrate availability.

Methods We conducted a double labeling pot experiment with either maize (Zea mays L.) or cup plant (Silphium perfoliatum L.) of the same age but differing in size of their shoot and root systems. The ${ }^{15} \mathrm{~N}$ gas flux method was applied to directly quantify $\mathrm{N}_{2} \mathrm{O}$ and $\mathrm{N}_{2}$ fluxes in situ. To link denitrification with available $\mathrm{C}$ in
\end{abstract}

Responsible Editor: Jorge Durán.

Supplementary Information The online version contains supplementary material available at https://doi.org/10.1007 /s11104-020-04750-7.

P. S. Rummel $(\bowtie) \cdot$ B. Pfeiffer $\cdot$ K. Dittert

Division of Plant Nutrition and Crop Physiology, Department of Crop Science, University of Göttingen, Göttingen, Germany

e-mail: pauline.rummel@uni-goettingen.de

R. Well

Thünen Institute of Climate-Smart Agriculture, Federal Research Institute for Rural Areas, Forestry and Fisheries, Braunschweig,

Germany

B. Pfeiffer

Institute of Microbiology and Genetics, Department of Genomic and Applied Microbiology, University of Göttingen, Göttingen, Germany

S. Floßmann · J. Pausch

Agroecology, Faculty for Biology, Chemistry, and Earth Sciences, University of Bayreuth, Bayreuth, Germany the rhizosphere, ${ }^{13} \mathrm{CO}_{2}$ pulse labeling was used to trace $\mathrm{C}$ translocation from shoots to roots and its release by roots into the soil.

Results Plant water and $\mathrm{N}$ uptake were the main factors controlling daily $\mathrm{N}_{2} \mathrm{O}+\mathrm{N}_{2}$ fluxes, cumulative $\mathrm{N}$ emissions, and $\mathrm{N}_{2} \mathrm{O}$ production pathways. Accordingly, pool-derived $\mathrm{N}_{2} \mathrm{O}+\mathrm{N}_{2}$ emissions were 30-40 times higher in the treatment with highest soil $\mathrm{NO}_{3}{ }^{-}$content and highest soil moisture. $\mathrm{CO}_{2}$ efflux from soil was positively correlated with root dry matter, but we could not detect any relationship between root-derived $\mathrm{C}$ and $\mathrm{N}_{2} \mathrm{O}+\mathrm{N}_{2}$ emissions.

Conclusions Root-derived C may stimulate denitrification under small plants, while $\mathrm{N}$ and water uptake become the controlling factors with increasing plant and root growth.

Keywords Nitrous oxide $\cdot$ Dinitrogen $\cdot$ Nitrogen mineralization $\cdot$ Rhizodeposition $\cdot{ }^{15} \mathrm{~N}^{13} \mathrm{C}$ labeling . Carbon cycling

\section{Introduction}

Soil conditions for denitrification have frequently been studied with the main prerequisites being availability of nitrate $\left(\mathrm{NO}_{3}{ }^{-}\right)$and easily decomposable organic substances, and oxygen deficiency (Burford and Bremner 1975; Firestone et al. 1979). Growing plants modify all these parameters, particularly the availability of the main substrates $\left(\mathrm{NO}_{3}{ }^{-}\right.$and $\left.\mathrm{C}_{\mathrm{org}}\right)$ and soil moisture, and 
may thus play an important role in regulating denitrification in situ (von Rheinbaben and Trolldenier 1984).

Plant $\mathrm{N}$ uptake largely controls concentration and distribution of mineral $\mathrm{N}$ in soils. Amounts and rates of plant $\mathrm{N}$ uptake depend on plant species, age, physiological status, root size, and nutritional status. $\mathrm{N}$ uptake rates of maize and cereals remain low during the first two months of growth, then increase linearly with increasing biomass reaching a maximum around the time of flowering (Novák and Vidovič 2003, Malhi et al. 2011).

Plant roots contribute to organic $\mathrm{C}$ input to the soil through rhizodeposition and decaying roots and root hairs. Thus, total and available concentration of $\mathrm{C}_{\mathrm{org}}$ is higher in the rhizosphere compared to bulk soil (Cheng et al. 1993). The amount of rhizodeposited $\mathrm{C}$ and its quality depend on plant species, age, and development (Gransee and Wittenmayer 2000; Vancura 1964; Vancura and Hovadik 1965), and plant nutrient status (Carvalhais et al. 2011). In general, younger plants translocate a higher share of assimilated $\mathrm{C}$ belowground than mature plants (Kuzyakov and Domanski 2000; Nguyen 2003), and perennial plants translocate a higher share of assimilated $\mathrm{C}$ belowground than annual plants (Husáková et al. 2018; Pausch and Kuzyakov 2018).

$\mathrm{C}$ and $\mathrm{N}$ availability are closely interrelated in the rhizosphere: Under low mineral $\mathrm{N}$ concentrations, root morphology is altered, and exudation related to root mass is increased (Paterson and Sim 1999). In addition, the composition of maize root exudates is altered under $\mathrm{N}$ deficiency (Carvalhais et al. 2011). On the other side, $\mathrm{N}$ fertilization decreases the portion of below-ground translocated C (Kuzyakov and Domanski 2000).

Several studies have tried to disentangle the effects of $\mathrm{N}$ and $\mathrm{C}$ availability on denitrification with contradictive results. Higher denitrification rates were measured from planted compared to bare soil (Senbayram et al. 2020; Vinther 1984). Some studies showed a strong influence of roots (Philippot et al. 2009), increasing denitrification rates with increasing root biomass (Klemedtsson et al. 1987), and higher potential denitrification activity in rhizosphere soil compared to bulk soil (Hamonts et al. 2013; Malique et al. 2019). Higher denitrification rates in planted soils have been associated with higher $\mathrm{C}_{\mathrm{org}}$ availability in the rhizosphere (Bakken 1988; Philippot et al. 2009). In addition, denitrification rates correlated with soil $\mathrm{NO}_{3}{ }^{-}$content (Philippot et al. 2009; von Rheinbaben and Trolldenier 1984). In contrast, other studies found no differences between planted and unplanted soil (Haider et al. 1985). Denitrification was increased only with poorly growing plants (von Rheinbaben and Trolldenier 1984) or when root biomass started to decrease (Haider et al. 1987), and $\mathrm{NO}_{3}{ }^{-}$ availability did not affect denitrification (Haider et al. 1987; Hamonts et al. 2013). The majority of these studies measured potential denitrification applying the acetylene inhibition method (Yoshinari and Knowles 1976), which is considered outdated due to a number of drawbacks such as inhibiting nitrification (Groffman et al. 2006).

Accordingly, it is still unclear whether growing plants stimulate denitrification through root exudation or restrict it through $\mathrm{NO}_{3}{ }^{-}$uptake. Reliable measurements of $\mathrm{N}_{2}$ fluxes and $\mathrm{N}_{2} \mathrm{O} /\left(\mathrm{N}_{2} \mathrm{O}+\mathrm{N}_{2}\right)$ ratios in the presence of plants are scarce. Direct measurement of $\mathrm{N}_{2}$ fluxes is only possible in either artificial $\mathrm{N}_{2}$-free atmosphere (Scholefield et al. 1997, Senbayram et al. 2020) or by applying highly enriched ${ }^{15} \mathrm{~N}$ labeled $\mathrm{NO}_{3}{ }^{-}$ (Hauck and Melsted 1956). The latter is used in the ${ }^{15} \mathrm{~N}$ gas flux technique which enables direct quantification of $\mathrm{N}_{2} \mathrm{O}$ and $\mathrm{N}_{2}$ produced from the labelled $\mathrm{NO}_{3}{ }^{-}$ pool and estimation of processes contributing to $\mathrm{N}_{2} \mathrm{O}$ and $\mathrm{N}_{2}$ formation including denitrification, co-denitrification, or nitrification and nitrifier denitrification (Buchen et al. 2016, Laughlin and Stevens 2002).

This study aimed to directly quantify $\mathrm{N}_{2} \mathrm{O}$ and $\mathrm{N}_{2}$ fluxes from soil with plants of the same age but different size of shoot and root systems and to relate denitrification to $\mathrm{C}$ availability from root exudation. As plant water uptake may also affect denitrification (von Rheinbaben and Trolldenier 1984), we aimed to keep soil moisture constant by continuous irrigation. We hypothesized that (I) plant $\mathrm{N}$ uptake governs $\mathrm{NO}_{3}{ }^{-}$ availability for denitrification. When plant $\mathrm{N}$ uptake is low due to smaller root system or root senescence, $\mathrm{N}_{2} \mathrm{O}$ and $\mathrm{N}_{2}$ emissions are increased. (II) Denitrification is stimulated by higher $\mathrm{C}_{\text {org }}$ availability from root exudation or decaying roots increasing total gaseous $\mathrm{N}$ emissions and decreasing their $\mathrm{N}_{2} \mathrm{O} /\left(\mathrm{N}_{2} \mathrm{O}+\mathrm{N}_{2}\right)$ ratios.

\section{Materials and methods}

\section{Experimental concept}

The experiment consisted of a pre-cultivation phase followed by the experimental phase. A schematic overview of both phases is presented in Fig. 1. In the pre- 


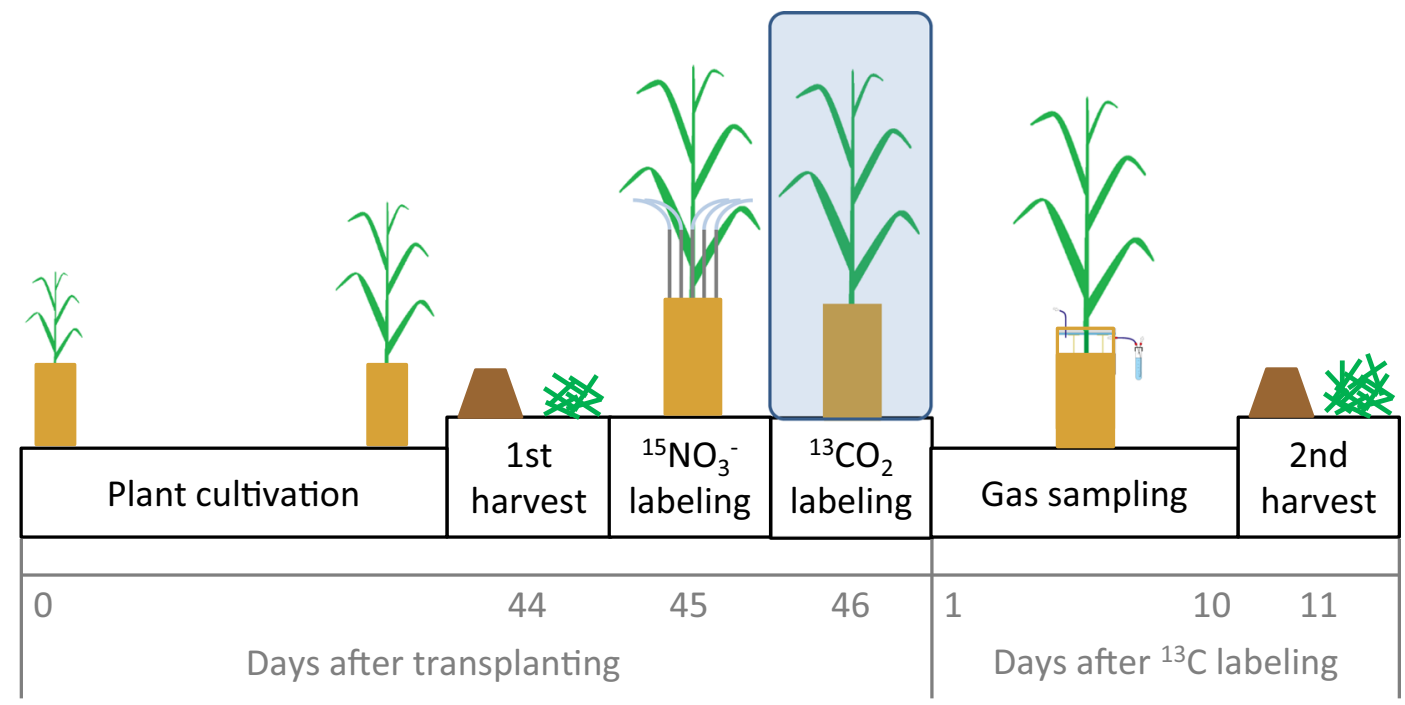

Fig. 1 Timeline of the experiment: pre-cultivation phase from day 0-46 and experimental phase from day 47-57 after transplanting

cultivation phase, plants were raised under controlled conditions. Maize plants (Zea mays L. cv. Ronaldinio) were grown under different $\mathrm{N}$ fertilization to obtain plants with different root and shoot biomass. As a second species, cup plant (Silphium perfoliatum L.) was included, a bioenergy plant that can produce similar aboveground biomass as maize (Gansberger et al. 2015) but has a higher root:shoot ratio. As cup plant is a perennial plant, it likely transfers more $\mathrm{C}$ belowground and exudes more organic substances than maize (Husáková et al. 2018; Pausch and Kuzyakov 2018). In all treatments, the $\mathrm{N}$ supply was scheduled to assure that at the end of the pre-cultivation phase, the soils were equally depleted in plant available N. With respect to background $\mathrm{N}$ supply, this permitted nearly equal starting conditions for the subsequent stable isotope labeling experiment.

To account for all necessary measurements, each treatment was replicated 19 times (Table 1). At the end of the pre-cultivation phase, the first set of replicates (1-
6) was harvested to determine shoot and root biomass, $\mathrm{N}$ and $\mathrm{C}$ content, and ${ }^{15} \mathrm{~N}$ and ${ }^{13} \mathrm{C}$ background concentrations. The second set of replicates (7-12) was labeled with ${ }^{15} \mathrm{NO}_{3}{ }^{-}$and ${ }^{13} \mathrm{CO}_{2}$, and gases evolving from soil were measured for the following 10 days. At the end of the experiment, replicates 7-12 were harvested. Replicate 13 was used to determine ${ }^{13} \mathrm{C}$ uptake during ${ }^{13} \mathrm{CO}_{2}$ pulse labeling and replicates 14-19 were used to determine ${ }^{13} \mathrm{C}$ background values in soil-emitted $\mathrm{CO}_{2}$.

Pre-experimental plant cultivation

The soil for the experiment was collected from a longterm experimental field site of the Höhere Landbauschule Rotthalmünster, Germany (latitude $\mathrm{N} 48^{\circ} 21^{\prime}$, longitude E13 $11^{\prime}$, elevation $360 \mathrm{~m}$ above sea level) in summer 2016. It was sieved to $10 \mathrm{~mm}$, air dried, and stored at $4{ }^{\circ} \mathrm{C}$ until setup of the experiment. The soil was classified as a Haplic Luvisol with a silty loam texture (19\% clay, $71 \%$ silt, $10 \%$ sand). Soil

Table 1 Overview of replicates in the experiment

\begin{tabular}{|c|c|c|c|}
\hline Replicate & Labeling & Sampling of plants and soil & Details \\
\hline $1-6$ & - & 1st harvest (44 days) & Determination of dry matter, $\mathrm{C}$ and $\mathrm{N}$ background values \\
\hline $7-12$ & ${ }^{15} \mathrm{NO}_{3}{ }^{-}$and ${ }^{13} \mathrm{CO}_{2}$ & Final harvest (57 days) & $\begin{array}{l}\text { Measurement of } \mathrm{N}_{2} \mathrm{O}, \mathrm{N}_{2} \text {, and } \mathrm{CO}_{2} \text {, determination of dry matter, } \\
\quad \text { total } \mathrm{C} \text { and } \mathrm{N},{ }^{13} \mathrm{C} \text { and }{ }^{15} \mathrm{~N} \text { content }\end{array}$ \\
\hline 13 & ${ }^{13} \mathrm{CO}_{2}$ & $\begin{array}{l}\text { Plants sampled directly after } \\
{ }^{13} \mathrm{CO}_{2} \text { labeling }\end{array}$ & Determination of total ${ }^{13} \mathrm{CO}_{2}$ uptake during labeling \\
\hline $14-19$ & $\begin{array}{l}\text { Treated similar to } 7-12 \text {, } \\
\text { but not labeled }\end{array}$ & $\begin{array}{l}\text { No sampling of plants and } \\
\text { soil }\end{array}$ & Determination of ${ }^{13} \mathrm{C}$ background in $\mathrm{CO}_{2}$ \\
\hline
\end{tabular}


properties were: total C $1.23 \%$, total N $0.14 \%$, C:N 8.76, $\mathrm{pH}\left(\mathrm{CaCl}_{2}\right) 6.74$.

Seven $\mathrm{kg}$ dry soil was mixed with fertilizers $(0.14 \mathrm{~g} \mathrm{P}$ $\mathrm{kg}^{-1}$ as $\mathrm{Ca}\left(\mathrm{H}_{2} \mathrm{PO}_{4}\right)_{2}, 0.2 \mathrm{~g} \mathrm{~K} \mathrm{~kg}^{-1}$ as $\mathrm{K}_{2} \mathrm{SO}_{4}$ and $0.04 \mathrm{~g}$ $\mathrm{Mg} \mathrm{kg}^{-1}$ as $\mathrm{MgSO}_{4} * 7 \mathrm{H}_{2} \mathrm{O}$ including $0.135 \mathrm{~g} \mathrm{~S} \mathrm{~kg}^{-1}$ ) and filled in pots of $15 \mathrm{~cm}$ diameter and $35 \mathrm{~cm}$ height to a bulk density of $1.3 \mathrm{~g} \mathrm{~cm}^{-3}$. Soil moisture was adjusted to $60 \%$ water holding capacity (WHC, $21.9 \%$ gravimetric water content) and watered regularly. TDR soil moisture sensors (Decagon Devices, Pullman, USA) were used to monitor soil water content during plant growth.

Maize seeds (Zea mays L. cv. Ronaldinio) were germinated on wet paper for 4 days. Cup plant (Silphium perfoliatum L.) had been pre-cultivated for 2 years in $5 \mathrm{~cm}$-pots and had 2-4 leaves. Per pot, either one germinated maize seed or one cup plant seedling was transplanted. Plants were cultivated in a climate chamber (Weiss, Loughborough, UK) with a diurnal cycle of $16 \mathrm{~h}$ day (light intensity $300 \mu \mathrm{mol} \mathrm{m} \mathrm{m}^{-2} \mathrm{~s}^{-1}$, air temperature $25{ }^{\circ} \mathrm{C}$, relative humidity $50 \%$ ) and $8 \mathrm{~h}$ night $\left(18{ }^{\circ} \mathrm{C}, 60 \%\right)$. Daytime included $4 \mathrm{~h}$ sunrise and $4 \mathrm{~h}$ sunset when light intensity, temperature, and relative humidity were gradually adjusted. All pots were fully randomized weekly to avoid microclimatic effects.

Maize $\mathrm{N}$ fertilization differed between treatments to achieve plants of different size: Maize $\mathrm{S}$ (no $\mathrm{N}$ fertilization, small plants), Maize $\mathrm{M}\left(0.05 \mathrm{~g} \mathrm{~N} \mathrm{~kg}^{-1}(0.35 \mathrm{~g} \mathrm{~N}\right.$ pot ${ }^{-1}$, as $\mathrm{NH}_{4} \mathrm{NO}_{3}$ split in 7 doses), medium sized plants), and Maize L (0.086 $\mathrm{g} \mathrm{N} \mathrm{kg}^{-1}\left(0.6 \mathrm{~g} \mathrm{~N}_{\text { pot }}{ }^{-1}\right.$, as $\mathrm{NH}_{4} \mathrm{NO}_{3}$ split in 7 doses), large plants). Cup plants were fertilized like Maize $\mathrm{M}\left(0.05 \mathrm{~g} \mathrm{~N} \mathrm{~kg}^{-1}(0.35 \mathrm{~g} \mathrm{~N}\right.$ pot ${ }^{-1}$, as $\mathrm{NH}_{4} \mathrm{NO}_{3}$ split in 7 doses)).

Experimental ${ }^{15} \mathrm{NO}_{3}{ }^{-}$and ${ }^{13} \mathrm{CO}_{2}$ pulse labeling

Replicates 7-12 of each treatment received $0.1 \mathrm{~g} \mathrm{~N} \mathrm{~kg}^{-1}$ ${ }^{15} \mathrm{~N}$-labeled $\mathrm{Ca}\left(\mathrm{NO}_{3}\right)_{2}\left(\sim 60\right.$ at\% ${ }^{15} \mathrm{~N}_{2}$, Campro Scientific GmbH, Berlin, Germany) 45 days after transplanting. The tracer was dissolved in $\mathrm{H}_{2} \mathrm{O}_{\text {dest }}$ and applied by injection with stainless steel needles as described by Buchen et al. (2016). Briefly, ${ }^{15} \mathrm{~N}$ fertilizer solution was injected via 12 needles to 6 depths $(2.5$, $7.5,12.5,17.5,22.5$ and $27.5 \mathrm{~cm}$ ) aiming for optimal three-dimensional homogenous label distribution $(\mathrm{Wu}$ et al. 2011). Per injection point, $10 \mathrm{ml}$ tracer solution were injected via a peristaltic pump (Ismatec, Wertheim, Germany) to simultaneously increase soil water content to $75 \%$ water-filled pore space (WFPS, equivalent to $80 \%$ WHC).

After injection of ${ }^{15} \mathrm{~N}$ tracer solution, all pots were closed with acrylic glass lids with a hole for the plant shoot, leaving a small headspace $(2-3 \mathrm{~cm})$ between soil surface and lid. Pots were then sealed with silicone paste (Tacosil 171, Thauer \& Co. KG, Dresden, Germany). Plants were labeled with ${ }^{13} \mathrm{C}$ in four separate chambers made from translucent greenhouse film (one for each treatment Maize S, Maize M, Maize L, and Cup plant). In each chamber, ${ }^{15} \mathrm{~N}$ labeled replicates $7-12$ and the non-labeled replicate 13 were labeled with ${ }^{13} \mathrm{C}$. To enrich the chamber atmosphere with ${ }^{13} \mathrm{CO}_{2}, 60 \mathrm{ml}$ of $5 \mathrm{M} \mathrm{H}_{2} \mathrm{SO}_{4}$ were added to $5 \mathrm{~g} \mathrm{Na}_{2}{ }^{13} \mathrm{CO}_{3}$ (99 at\%) dissolved in $\mathrm{H}_{2} \mathrm{O}_{\text {dest }}$ in each chamber. For internal chamber ventilation, two fans were installed. The plants were pulse labeled in the ${ }^{13} \mathrm{CO}_{2}$ enriched atmosphere for $5 \mathrm{~h}$. Before opening each chamber, an air sample was analyzed for $\mathrm{CO}_{2}$ concentration to ensure that maximum amounts of $\mathrm{CO}_{2}$ had been taken up by plants. Chambers were opened and $\mathrm{CO}_{2}$ evolving from the soil was trapped. Replicate 13 was harvested directly after chamber opening to estimate the amount of ${ }^{13} \mathrm{C}$ assimilated during labeling.

To determine natural abundance background of ${ }^{13} \mathrm{C}$ in $\mathrm{CO}_{2}$, replicates 14-19 were used. $0.1 \mathrm{~g} \mathrm{~N} \mathrm{~kg}^{-1}$ was injected using $\mathrm{Ca}\left(\mathrm{NO}_{3}\right)_{2} * 6 \mathrm{H}_{2} \mathrm{O}$ dissolved in $\mathrm{H}_{2} \mathrm{O}_{\text {bidest }}$, and pots were sealed using the same methods as described above.

\section{Irrigation}

After pots had been sealed with silicon paste, plants were irrigated by injecting water through a valve on the bottom of the pots. To irrigate pots without applying too much pressure, peristaltic pumps (Watson-Marlow, Zollikon, Switzerland) with a pumping rate of $1.5 \mathrm{ml}$ $\min ^{-1}$ were used. Target soil moisture was $75 \%$ waterfilled pore space (WFPS, equivalent to $80 \%$ WHC) during the gas sampling phase. To estimate irrigation demand, TDR soil moisture sensors (Decagon Devices, Pullman, USA) were used to monitor soil water content during the experiment in one replicate for each treatment. In addition, all pots were weighed one, three, and five days after ${ }^{13} \mathrm{C}$ labeling to compare whether irrigation demand differed between pots. As pot weights were comparable within treatments, sensor data were used to compare soil moisture. 
Gas sampling

One additional pot was filled with dry quartz sand, sealed with silicone paste as described before, and used as a reference to determine background gas concentrations. To flush the headspace of all pots with $\mathrm{CO}_{2}$-free air, pressurized air was first run through a glass column filled with soda lime (pellets made of $\mathrm{NaOH}$ and $\mathrm{Ca}(\mathrm{OH})_{2}$ mixture) to remove $\mathrm{CO}_{2}$. For trapping $\mathrm{CO}_{2}$ emitted from soils, the outlet tubes of the pots' headspaces were connected to glass tubes containing $15 \mathrm{ml}$ of $1 M \mathrm{NaOH}$ solution. Starting one day after labeling, $\mathrm{NaOH}$ solution was changed in intervals of 6,12 , or 24 hours. To determine ${ }^{13} \mathrm{C}$ background in $\mathrm{CO}_{2}$, replicates 14-19 were treated similarly: the headspaces were flushed for 6 hours and $\mathrm{CO}_{2}$ was trapped in glass tubes containing $15 \mathrm{ml}$ of $1 \mathrm{MNaOH}$ solution. To estimate the total $\mathrm{CO}_{2}$ efflux, the $\mathrm{C}$ concentration of the $\mathrm{NaOH}$ solutions was determined with a TIC-analyzer (multi N/C 2100S, Analytik Jena, Jena, Germany). For ${ }^{13} \mathrm{C}$ measurements, $\mathrm{CO}_{2}$ trapped in $\mathrm{NaOH}$ was precipitated as $\mathrm{SrCO}_{3}$ with an excess of $1 \mathrm{M} \mathrm{SrCl}_{2}$ solution. The precipitants were centrifuged, washed with deionized water until the $\mathrm{pH}$ was neutral, the precipitate was frozen, and then freeze-dried with a rotation vacuum concentrator (RVC 2-25 CDplus, Martin Christ, Osterode am Harz, Germany) and a cooling trap (CT 02-50, Martin Christ, Osterode am Harz, Germany), both connected to a vacuum pump.

${ }^{13} \mathrm{C}$ enrichment in precipitated $\mathrm{SrCO}_{3}$ was analyzed: Natural abundance samples were measured on an elemental analyzer NA 11,100 (CE Instruments, Milano, Italy) linked to a Delta Plus gas-isotope ratio mass spectrometer (Finnigan MAT, Bremen, Germany) via a ConFlo III interface (Finnigan MAT, Bremen, Germany). For enriched samples, depending on capacity, one of the following combinations was used: (i) elemental analyzer Flash 2000 (Thermo Fisher Scientific, Cambridge, UK) linked to a Delta V Advantage gas-isotope ratio mass spectrometer (Thermo Electron, Bremen, Germany) via a ConFlo III interface (Thermo Electron, Bremen, Germany), or (ii) elemental analyzer NA1108 (Fisons-Instruments, Milan, Italy) linked to a Delta C gas-isotope ratio mass spectrometer (Finnigan MAT, Bremen, Germany) via a ConFlo III interface (Thermo Electron Cooperation, Bremen, Germany).

For $\mathrm{N}_{2} \mathrm{O}$ and $\mathrm{N}_{2}$ sampling, the airflow through the pots' headspace was interrupted to accumulate gases in the headspace. After $1 \mathrm{~h}$, duplicate samples were taken using a syringe and filled in pre-evacuated 12-ml Exetainer® glass vials (Labco, High Wycombe, UK). Samples were analyzed for $\mathrm{N}_{2} \mathrm{O}$ concentration using a gas chromatograph (GC 7890A, Agilent, Santa Clara, USA). The analytical precision of the GC was determined by repeated measurements of standard gases $\left(300 \mathrm{ppb} \mathrm{N}_{2} \mathrm{O}\right.$ ) and was consistently $<3 \%$. The second duplicate was analyzed for $m / z, 28\left({ }^{14} \mathrm{~N}^{14} \mathrm{~N}\right), 29$ $\left({ }^{14} \mathrm{~N}^{15} \mathrm{~N}\right)$ and $30\left({ }^{15} \mathrm{~N}^{15} \mathrm{~N}\right)$ of $\mathrm{N}_{2}$ using a modified GasBench II preparation system coupled to an isotope ratio mass spectrometer (MAT 253, Thermo Fisher Scientific, Bremen, Germany) according to LewickaSzczebak et al. (2013). This system allows a simultaneous determination of mass ratios ${ }^{29} \mathrm{R}(29 / 28)$ and ${ }^{30} \mathrm{R}$ (30/28) of three separated gas species $\left(\mathrm{N}_{2}, \mathrm{~N}_{2}+\mathrm{N}_{2} \mathrm{O}\right.$, and $\mathrm{N}_{2} \mathrm{O}$ ), all measured as $\mathrm{N}_{2}$ gas after $\mathrm{N}_{2} \mathrm{O}$ reduction in a Cu oven. Typical repeatability of ${ }^{29} \mathrm{R}$ and ${ }^{30} \mathrm{R}$ ( $1 \sigma$ of 3 replicate measurements) was $5 \times 10^{-7}$ for both values. For each of the analyzed gas species, the fraction originating from the ${ }^{15} \mathrm{~N}$-labeled pool with respect to total $\mathrm{N}$ in the gas sample $(F p)$ as well as the ${ }^{15} \mathrm{~N}$ enrichment of the active ${ }^{15} \mathrm{~N}$-labeled $\mathrm{N}$ pool $\left(\mathrm{a}_{\mathrm{p}}\right)$ producing $\mathrm{N}_{2} \mathrm{O}$ $\left(a_{p} \mathrm{~N}_{2} \mathrm{O}\right)$ or $\mathrm{N}_{2}+\mathrm{N}_{2} \mathrm{O}\left(\mathrm{a}_{\mathrm{p} \_\mathrm{N} 2+\mathrm{N} 2 \mathrm{O}}\right)$ were calculated after Spott et al. (2006) as described in Lewicka-Szczebak et al. (2017).

Harvest and analyses of plant and soil material

Before labeling (44 days after transplanting), replicates 1-6 were harvested. Eleven days after ${ }^{13} \mathrm{C}$ labeling (57 days after transplanting), all labeled plants (replicates 712) were harvested. At both harvests, plants were separated into shoots and roots including maize crown roots. As all pots were densely rooted, a separation of rhizosphere and bulk soil was not possible. Roots were shaken gently to separate them from soil and washed. From replicates 7-12, a subsample of root washing water was analyzed for water-extractable organic $\mathrm{C}$ (WEOC) and the amount of ${ }^{13} \mathrm{C}$ lost during root washing was determined. To estimate their amount in soil, fine roots were picked by hand from a subsample of soil $(\sim 400 \mathrm{~g}$ soil) for a defined time. All plant material and a soil subsample were dried at $60^{\circ} \mathrm{C}$, milled in a ball mill and analyzed for total $\mathrm{C},{ }^{13} \mathrm{C}$, total $\mathrm{N}$, and ${ }^{15} \mathrm{~N}$ content using an elemental analyzer coupled to a gas-isotope ratio mass spectrometer as described earlier. For determination of water-extractable organic $\mathrm{C}$ (WEOC) content, a subsample of fresh soil was analyzed according to Chantigny et al. (2007). Briefly, fresh soil was 
homogenized with deionized water (1:2 w/v). Samples were centrifuged and filtered with $0.45 \mu \mathrm{m}$ polyether sulfone filters (Labsolute, Renningen, Germany), split in two subsamples and stored at $-20{ }^{\circ} \mathrm{C}$. The extracts were analyzed for total $\mathrm{C}$, organic $\mathrm{C}$, and total $\mathrm{N}$ content using a multi N/C® Analyzer (Analytik Jena, Jena, Germany).

For determination of soil mineral $\mathrm{N}$ content, a subsample of $50 \mathrm{~g}$ was frozen at $-20{ }^{\circ} \mathrm{C}$. Frozen samples were extracted with a $2 M \mathrm{KCl}$ solution $(1: 5 \mathrm{w} / \mathrm{v})$ for $60 \mathrm{~min}$ on an overhead shaker ( $85 \mathrm{rpm})$. The extracts were filtered with $615 \%$ filter paper (Macherey - Nagel GmbH \& Co. KG, Düren, Germany), split in two subsamples, and stored at $-20{ }^{\circ} \mathrm{C}$. The extracts were analyzed colorimetrically for the concentrations of $\mathrm{NO}_{3}{ }^{-}$ and $\mathrm{NH}_{4}{ }^{+}$using a $\mathrm{San}^{++}$continuous flow Analyzer (Skalar Analytical B.V., Breda, The Netherlands). ${ }^{15} \mathrm{~N}$ concentration in $\mathrm{NH}_{4}{ }^{+}$and $\mathrm{NO}_{3}{ }^{-}$was analyzed using an automated sample preparation unit for inorganic nitrogen coupled to a membrane inlet quadrupole mass spectrometer (QMS, GAM 200, InProcess, Bremen, Germany) as described in detail by Eschenbach et al. (2017, 2018). In parallel subsamples, soil water content was determined by oven drying at $105^{\circ} \mathrm{C}$.

\section{Calculations and statistics}

Plant $\mathrm{N}$ uptake was calculated by multiplying dry mass with the respective tissue $\mathrm{N}$ content (root, shoot).

Cumulative $\mathrm{CO}_{2}$ emissions were calculated from $\mathrm{CO}_{2}$ trapped in $\mathrm{NaOH}, \mathrm{CO}_{2}$ fluxes were calculated by dividing cumulative $\mathrm{CO}_{2}$ through the respective trapping time $(6,12$, or $24 \mathrm{~h}) .{ }^{13} \mathrm{C}$ recovery in $\mathrm{CO}_{2}$ ${ }^{13} C_{\text {recovery; }}$ CO2, $\mathrm{mg}$ ) was calculated as the excess (above background) ${ }^{13} \mathrm{C}$ concentration multiplied with the total $\mathrm{CO}_{2}$ trapped $\left(\mathrm{CO}_{2}, \mathrm{mg} \mathrm{CO}_{2}-\mathrm{C}\right)$ :

$$
{ }^{13} \mathrm{C}_{\text {recovery } ; \mathrm{CO}_{2}}=\left({ }^{13} \mathrm{C}_{\mathrm{CO}_{2}}-{ }^{13} \mathrm{C}_{\mathrm{NA} ; \mathrm{CO}_{2}}\right) * \mathrm{CO}_{2}
$$

where ${ }^{13} \mathrm{C}_{\mathrm{CO} 2}$ is the ${ }^{13} \mathrm{C}$ enrichment of $\mathrm{CO}_{2}$ (at\%) trapped after labeling and ${ }^{13} C_{N A} ; \mathrm{CO} 2$ is the natural ${ }^{13} \mathrm{C}$ background (at $\%$ ) from unlabeled plants (replicates 14 19). ${ }^{13} \mathrm{C}$ recovery in soil $\left({ }^{13} C_{\text {recovery; soil }}, \mathrm{mg}\right)$ was calculated as follows:

$$
\begin{aligned}
{ }^{13} C_{\text {recovery;soil }}= & \left({ }^{13} C_{\text {soil }}-{ }^{13} C_{N A ; s o i l}\right) * C_{\text {soil }} \\
& * \text { mass }_{\text {soil }}
\end{aligned}
$$

where ${ }^{13} C_{\text {soil }}$ is the enrichment of ${ }^{13} \mathrm{C}$ (at \%) of the soil C pool after labeling, ${ }^{13} C_{N A}$; soil is the natural abundance of ${ }^{13} \mathrm{C}$ in soil before labeling (at\%), $C_{\text {soil }}$ is the total content of $\mathrm{C}$ in soil $\left(\mathrm{mg} \mathrm{g}^{-1}\right)$, and mass soil $_{\text {is }}$ is the mass of soil per pot $(\mathrm{g})$. Relative ${ }^{13} C_{\text {recovery }}\left(\%\right.$ of recovered $\left.{ }^{13} \mathrm{C}\right)$ of a particular pool $\left(\mathrm{CO}_{2}\right.$, soil) was calculated by dividing the amount of ${ }^{13} \mathrm{C}$ recovered in that pool $\left({ }^{13} C_{\text {recovery; }}\right.$ pool) by the sum of the amount of ${ }^{13} \mathrm{C}$ recovered in all pools $\left(\mathrm{CO}_{2}\right.$, shoot, root, soil, root washing water).

Relative ${ }^{13} C_{\text {recovery }}=\frac{{ }^{13} C_{\text {recovery; pool }}}{\sum{ }^{13} C_{\text {recovery; pool }}} * 100$

Total $\mathrm{N}_{2} \mathrm{O}$ fluxes $\left(f_{\text {tot }}, \mu \mathrm{g} \mathrm{N} \mathrm{kg}{ }^{-1} \mathrm{~h}^{-1}\right)$ were calculated from GC measurements:

$f_{\text {tot }}=\frac{\left(C_{H}-C_{B}\right)}{t} * \frac{V}{m}$

where $C_{H}$ is the mass concentration in the headspace and $C_{B}$ is the background concentration in the reference pot $\left(\mu \mathrm{g} \mathrm{N} \mathrm{m}^{-3}\right)$ corrected by the chamber temperature according to the ideal gas law, $t$ is the accumulation time (h), $V$ is the volume of the headspace $\left(\mathrm{m}^{3}\right)$, and $m$ is the dry mass of soil per pot $(\mathrm{kg})$.

We calculated the ${ }^{15} \mathrm{~N}$ enrichment of the active $\mathrm{NO}_{3}{ }^{-}$ pool undergoing denitrification $\left(a p_{-} \mathrm{N}_{2} \mathrm{O}\right.$, ap $\mathrm{N}_{2} \mathrm{O}+$ $\mathrm{N}_{2}$ ) from the non-random distribution of $\mathrm{N}_{2}$ and/or $\mathrm{N}_{2} \mathrm{O}$ isotopologues using calculations by Spott et al. (2006) as described by Buchen et al. (2016) and Lewicka-Szczebak et al. (2017):

$a_{p}=\frac{{ }^{30} X_{m}-a_{b g d} * a_{m}}{a_{m}-a_{b g d}}$

where $a_{p}$ is the ${ }^{15} \mathrm{~N}$ abundance of the ${ }^{15} \mathrm{~N}$ labeled $\mathrm{NO}_{3}{ }^{-}$ pool undergoing denitrification, $a_{b g d}$ is the measured ${ }^{15} \mathrm{~N}$ abundance of atmospheric background $\mathrm{N}_{2}, a_{m}$ is the measured ${ }^{15} \mathrm{~N}$ abundance of $\mathrm{N}_{2}$ or $\mathrm{N}_{2} \mathrm{O}$

$a_{m}=\frac{{ }^{29} R+2 *{ }^{30} R}{2\left(1+{ }^{29} R+{ }^{30} R\right)}$

and ${ }^{30} x_{m}$ is the measured fraction of $\mathrm{m} / \mathrm{z} 30$ in $\mathrm{N}_{2}$ and converted $\mathrm{N}_{2} \mathrm{O}$ :

${ }^{30} x_{m}=\frac{{ }^{30} R}{1+{ }^{29} R+{ }^{30} R}$

The fraction of $\mathrm{N}$ derived from the active $\mathrm{NO}_{3}{ }^{-}$pool $(F p)$ was calculated using Eq. (8) if ${ }^{30} \mathrm{R}$ was significant and otherwise Eq. (9) was used. In the latter case, $a p \_N_{2} O$ was assumed to be identical with $a p N_{2}$ and ap_ $\mathrm{N}_{2} \mathrm{O}+\mathrm{N}_{2}$ and was thus used when calculating 
$\mathrm{Fp} \_\mathrm{N}_{2}$ and $\mathrm{Fp} \_\mathrm{N}_{2} \mathrm{O}+\mathrm{N}_{2}$ from Eq. 9. If $a p \_\mathrm{N}_{2} \mathrm{O}$ of a sampling date was not available, the mean value from the other replicates from the same sampling date was used as best estimate. $F p$ calculated from Eq. (9) with a given ${ }^{29} \mathrm{R}$ is relatively insensitive to changes in ap between 0.4 and 0.6 since the nominator yields values between 0.48 and 0.5 . Hence, uncertainty in the estimation of ap within that range causes minor uncertainty in calculated $F p$ (Well and Myrold 1999). Because ap values in our study were typically between 0.4 and 0.6 , we assume that uncertainty in $F p$ calculation from the missing of individual ap values was small.

$F p=\frac{a_{m}-a_{b g d}}{a_{p}-a_{b g d}}$

$F p=\left({ }^{29} R_{s a}-{ }^{29} R_{b g d}\right) /\left(2 a_{p}\left(1-a_{p}\right)\right)$

where lower case $s a$ and $b g d$ denote sample and background (ambient air), respectively.

$F p$ values were multiplied with respective total sample $\mathrm{N}$ concentration $\left(\mathrm{N}_{2} \mathrm{O}, \mathrm{N}_{2}\right)$ to obtain pool-derived gas concentrations (in ppm). Then, pool-derived fluxes $(f p)$ were calculated from concentrations similar to Eq. (4). The same calculations were used for $\mathrm{N}_{2} \mathrm{O}, \mathrm{N}_{2}$, and $\mathrm{N}_{2} \mathrm{O}+\mathrm{N}_{2}$, resulting in respective values for fractions of pool-derived $\mathrm{N}$ and for the respective ${ }^{15} \mathrm{~N}$ abundances of the active $\mathrm{N}$ pools $\left(a p_{-} \mathrm{N}_{2} \mathrm{O}\right.$, ap $\mathrm{N}_{2}$, ap_ $\mathrm{N}_{2} \mathrm{O}+\mathrm{N}_{2}$ ). Non-pool derived $\mathrm{N}_{2} \mathrm{O}$ fluxes were calculated by subtracting pool-derived $\mathrm{N}_{2} \mathrm{O}$ fluxes from total $\mathrm{N}_{2} \mathrm{O}$ fluxes.

The ratio of denitrification end products was calculated from pool-derived $\mathrm{N}_{2} \mathrm{O}\left(f p_{-} N_{2} \mathrm{O}\right)$ and $\mathrm{N}_{2} \mathrm{O}+\mathrm{N}_{2}$ $\left(f p \_N_{2} \mathrm{O}+\mathrm{N}_{2}\right)$ :

Product ratio $=\frac{f p \_N_{2} O}{f p \_N_{2} \mathrm{O}+N_{2}}$

Cumulative $\mathrm{N}_{2} \mathrm{O}, \mathrm{N}_{2}$, and $\mathrm{N}_{2} \mathrm{O}+\mathrm{N}_{2}$ emissions were calculated by linear interpolation of fluxes. The $\%$ of $\mathrm{N}_{2}+\mathrm{N}_{2} \mathrm{O}$ emitted with respect to added $\mathrm{N}$ was estimated by dividing cumulative pool-derived $\mathrm{N}_{2} \mathrm{O}+\mathrm{N}_{2}$ emission by the amount of $\mathrm{N}$ added with ${ }^{15} \mathrm{NO}_{3}{ }^{-}$labeling.

All statistical analyses were performed using the statistical software R version 3.6.0 (R Core Team 2019). Means and standard deviations were calculated over all replicates. For harvest data, cumulative $\mathrm{CO}_{2}$, and ${ }^{13} \mathrm{C}$ recovery a one-way ANOVA was calculated followed by Tukey's HSD post-hoc test at $p \leq 0.05$ to separate treatment effects. As cumulative $\mathrm{N}$ emissions were not normally distributed, the Kruskal-Wallis rank sum test was used followed by LSD post-hoc test at $\mathrm{p} \leq$ 0.05 to separate treatment effects. To compare soil and plant samples between harvests, and to test whether soil ${ }^{15} a_{-} \mathrm{NO}_{3}^{-}$contents at final harvest and $a p_{-} \mathrm{N}_{2} \mathrm{O}$ or $a p_{-}$ $\mathrm{N}_{2} \mathrm{O}+\mathrm{N}_{2}$ at last sampling date differed, a t-test was used at $p \leq 0.05$. Simple linear regression models were tested to analyze the effects of soil and plant parameters on $\mathrm{CO}_{2}$ and $\mathrm{N}$ fluxes and cumulative emissions.

\section{Results}

Plant growth after labeling

Shoot dry matter increased significantly in all treatments between the first and the second harvest, but differences between treatments did not change (Table 2, results of 1 st harvest are displayed in supplementary table $\mathrm{S} 1$ ). Root dry matter significantly decreased in Maize S and $M$ until the end of the experiment. Increases in root dry matter in Maize L and Cup plant were not significant. Root:shoot ratio decreased in all treatments but remained twice as high in cup plant compared to maize, which is typical for perennial plants compared to annual plants (Husáková et al. 2018). Nitrogen content increased in previously unfertilized Maize S plants and was similar in all maize treatments at the final harvest. Nitrogen content in cup plant shoots and roots was significantly greater than in all maize treatments and total $\mathrm{N}$ uptake corresponded with $\mathrm{N}$ fertilization Maize $\mathrm{L}>$ Maize $\mathrm{M}=$ Cup plant $>$ Maize $\mathrm{S}$. Soil $\mathrm{NO}_{3}{ }^{-}$content analyzed at the end of experiment was on average still twice as high in Maize S compared to all other treatments.

Total $\mathrm{N}_{2} \mathrm{O}$ and pool-derived $\mathrm{N}_{2} \mathrm{O}+\mathrm{N}_{2}$ fluxes and cumulative emissions

Total and pool-derived $\mathrm{N}$ fluxes were highest in Maize $\mathrm{S}$ but followed a similar pattern in all treatments (Fig. 2a + c). Total $\mathrm{N}_{2} \mathrm{O}$ fluxes strongly increased in Maize $\mathrm{S}$ reaching highest values on day $3\left(11.3 \mu \mathrm{g} \mathrm{N}_{2} \mathrm{O}-\mathrm{N} \mathrm{kg}^{-1}\right.$ $\mathrm{h}^{-1}$, Fig. 2a) and a second smaller peak on day $6(5.9 \mu \mathrm{g}$ $\mathrm{N}_{2} \mathrm{O}-\mathrm{N} \mathrm{kg}^{-1} \mathrm{~h}^{-1}$ ). Pool-derived $\mathrm{N}_{2} \mathrm{O}+\mathrm{N}_{2}$ fluxes followed a similar general pattern as total $\mathrm{N}_{2} \mathrm{O}$ fluxes (Fig. 2c) and peaks were detected at similar times as $\mathrm{N}_{2} \mathrm{O}$ peaks, in Maize $\mathrm{S}$ on day $3\left(48 \mu \mathrm{g} \mathrm{N} \mathrm{N}_{2}-\mathrm{N} \mathrm{kg}^{-1} \mathrm{~h}^{-1}\right)$ and larger 
Table 2 Harvest data of final harvest at the end of the experiment (replicates $7-12,57$ days after transplanting/ 11 days after ${ }^{13} \mathrm{CO}_{2}$ labeling)

\begin{tabular}{|c|c|c|c|c|c|c|c|c|c|c|c|c|}
\hline & Maize S & & & Maize M & & & Maize L & & & Cup Plant & & \\
\hline Shoot dry matter $\left(\mathrm{g} \mathrm{pot}^{-1}\right)$ & $63.5 \pm 2.7$ & $\mathrm{c}$ & $* * *$ & $89.8 \pm 4.0$ & $\mathrm{~b}$ & $* * *$ & $115.3 \pm 10.8$ & $\mathrm{a}$ & $* * *$ & $34.9 \pm 5.4$ & $\mathrm{~d}$ & $* * *$ \\
\hline Root dry matter $\left(\mathrm{g} \mathrm{pot}^{-1}\right)$ & $10.1 \pm 1.6$ & $\mathrm{c}$ & $* * *$ & $14.5 \pm 0.8$ & $\mathrm{~b}$ & $* * *$ & $21.5 \pm 4.2$ & $\mathrm{a}$ & & $19.7 \pm 1.8$ & $\mathrm{a}$ & \\
\hline Root : Shoot ratio & $0.16 \pm 0.02$ & $\mathrm{~b}$ & $* * *$ & $0.16 \pm 0.01$ & $\mathrm{~b}$ & $* * *$ & $0.19 \pm 0.02$ & $\mathrm{~b}$ & $* * *$ & $0.58 \pm 0.09$ & $\mathrm{a}$ & \\
\hline Shoot $\mathrm{N}$ content $(\%)$ & $1.19 \pm 0.04$ & $\mathrm{~b}$ & $* * *$ & $1.14 \pm 0.08$ & $\mathrm{~b}$ & $* * *$ & $1.05 \pm 0.14$ & $\mathrm{~b}$ & & $2.47 \pm 0.28$ & a & \\
\hline Root $\mathrm{N}$ content $(\%)$ & $1.06 \pm 0.10$ & $\mathrm{~b}$ & $* * *$ & $0.97 \pm 0.08$ & $\mathrm{~b}$ & & $0.95 \pm 0.08$ & $\mathrm{~b}$ & & 1.590 .19 & a & \\
\hline $\mathrm{NO}_{3}{ }^{-}$content $\left(\mathrm{mg} \mathrm{kg}^{-1}\right)$ & $3.39 \pm 2.01$ & a & & $1.54 \pm 1.02$ & $\mathrm{ab}$ & & $1.04 \pm 0.43$ & $\mathrm{~b}$ & & $1.61 \pm 0.83$ & $\mathrm{ab}$ & \\
\hline $\mathrm{NH}_{4}^{+}$content $\left(\mathrm{mg} \mathrm{kg}^{-1}\right)$ & $1.46 \pm 0.19$ & $\mathrm{ab}$ & $* * *$ & $1.94 \pm 0.36$ & $\mathrm{a}$ & $* * *$ & $1.64 \pm 0.25$ & $\mathrm{ab}$ & $* * *$ & $1.41 \pm 0.39$ & $\mathrm{~b}$ & $* * *$ \\
\hline WEOC content $\left(\mathrm{mg} \mathrm{kg}^{-1}\right)$ & $6.65 \pm 0.95$ & $\mathrm{a}$ & $* * *$ & $7.35 \pm 0.66$ & a & $* * *$ & $7.56 \pm 2.69$ & $\mathrm{a}$ & $* * *$ & $8.10 \pm 1.24$ & a & $* * *$ \\
\hline $\mathrm{N}$ uptake $($ shoot + root $)\left(\mathrm{g} \mathrm{pot}^{-1}\right)$ & $0.86 \pm 0.35$ & $\mathrm{c}$ & & $1.16 \pm 0.087$ & $\mathrm{~b}$ & & $1.41 \pm 0.054$ & $\mathrm{a}$ & & $1.17 \pm 0.044$ & $\mathrm{~b}$ & \\
\hline
\end{tabular}

Shoot dry matter includes cob dry matter

Different letters in one row indicate a significant difference $(p<0.05)$ between treatments

$* * *$ indicates a significant difference $(p<0.05)$ to first harvest

peaks on day $6.5\left(67 \mu \mathrm{g} \mathrm{N}_{2}-\mathrm{N} \mathrm{kg}^{-1} \mathrm{~h}^{-1}\right)$ and day 9.5 $\left(61 \mu \mathrm{g} \mathrm{N}_{2}-\mathrm{N} \mathrm{kg}^{-1} \mathrm{~h}^{-1}\right.$ ). Total $\mathrm{N}_{2} \mathrm{O}$ and pool-derived $\mathrm{N}_{2} \mathrm{O}+\mathrm{N}_{2}$ fluxes in all other treatments followed a similar pattern but on a lower scale. The product ratio $\left(\mathrm{N}_{2} \mathrm{O}\right.$ / $\left(\mathrm{N}_{2} \mathrm{O}+\mathrm{N}_{2}\right)$, Fig. 2d) of pool-derived fluxes followed a similar pattern in all treatments. The product ratio decreased for the first days after onset of incubation reaching values between 0.2 and 0.5 as $\mathrm{N}_{2}$ became the dominant end product of denitrification. It shortly increased and peaked on day 3.5 , then decreased again until day 6 to values between 0 and 0.2 . After day 6.5 , the product ratio ranged between 0 and 0.5 until the end.

Total and pool-derived cumulative $\mathrm{N}$ emissions were 20-43 times higher in Maize S compared to all other treatments (Table 3). No significant differences were detected between the other treatments. Similarly, recovery of added $\mathrm{NO}_{3}{ }^{-}$in $\mathrm{N}_{2} \mathrm{O}+\mathrm{N}_{2}$ was highest in Maize $\mathrm{S}$ and not significantly different in the other treatments. The mean $\mathrm{N}_{2} \mathrm{O} /\left(\mathrm{N}_{2} \mathrm{O}+\mathrm{N}_{2}\right)$ ratio ranged from 0.14 to 0.16 in maize treatments and was 0.24 in cup plant.
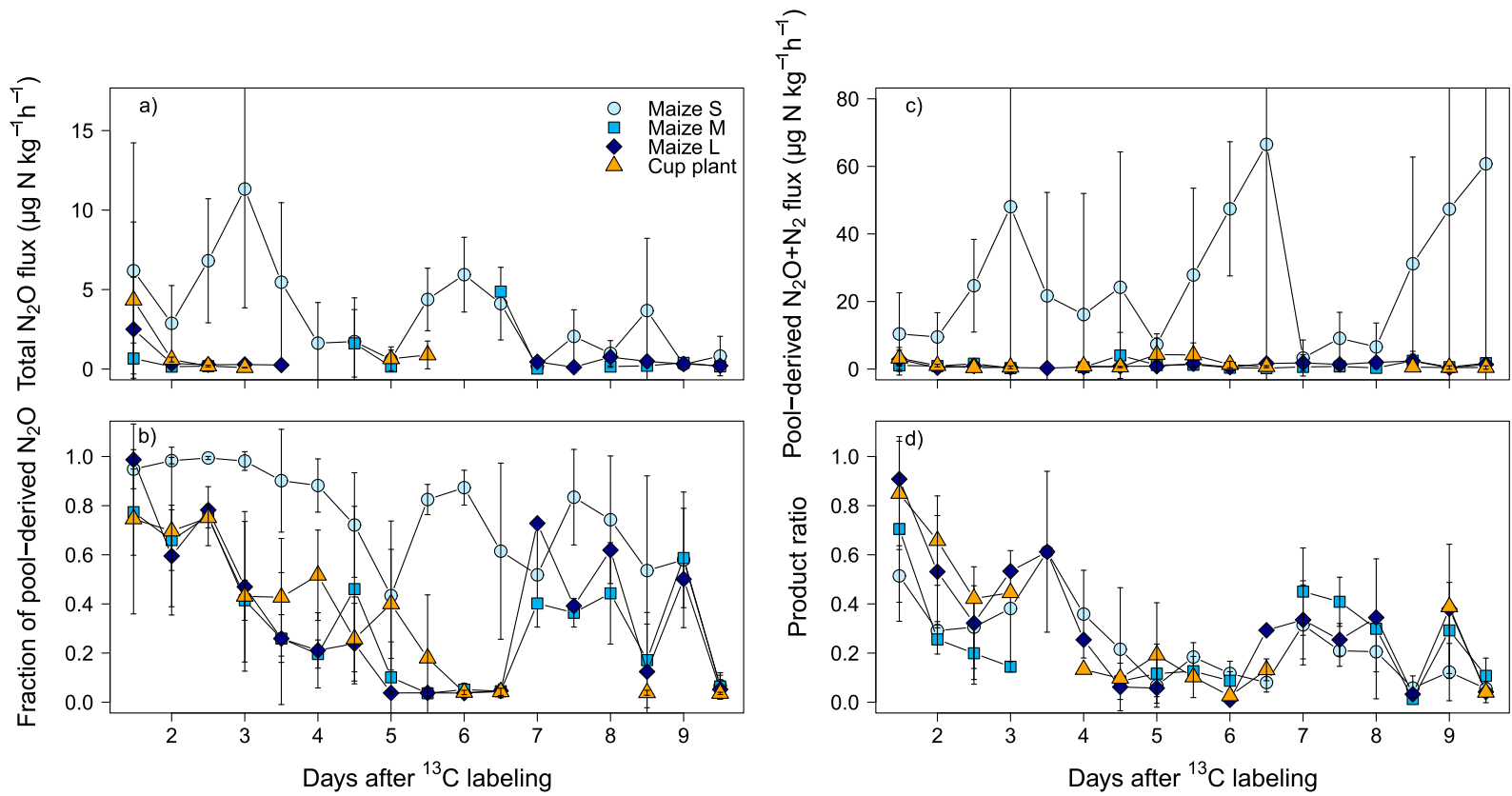

Fig. 2 Total $\mathrm{N}_{2} \mathrm{O}$ fluxes (a), fraction of pool-derived $\mathrm{N}_{2} \mathrm{O}\left(\mathrm{Fp} \_\mathrm{N}_{2} \mathrm{O}\right)(\mathbf{b})$, pool-derived $\mathrm{N}_{2} \mathrm{O}+\mathrm{N}_{2}$ fluxes $(\mathbf{c})$, and product ratio $\mathrm{N}_{2} \mathrm{O} /\left(\mathrm{N}_{2} \mathrm{O}+\right.$ $\mathrm{N}_{2}$ ) of pool-derived fluxes (d). Means and standard deviation for $\mathrm{n}=1-6$ 
Table 3 Total cumulative $\mathrm{N}_{2} \mathrm{O}$, pool-derived cumulative $\mathrm{N}_{2}$ and $\mathrm{N}_{2} \mathrm{O}+\mathrm{N}_{2}$ emissions, and product ratio of pool-derived fluxes

\begin{tabular}{|c|c|c|c|c|c|c|c|c|c|c|}
\hline & \multicolumn{2}{|c|}{$\begin{array}{l}\text { Total cumulative } \\
\mathrm{N}_{2} \mathrm{O}\end{array}$} & \multicolumn{2}{|l|}{$\begin{array}{l}\text { Pool-derived } \\
\text { cumulative } \mathrm{N}_{2}\end{array}$} & \multicolumn{2}{|c|}{$\begin{array}{l}\text { Pool-derived cumulative } \\
\mathrm{N}_{2} \mathrm{O}+\mathrm{N}_{2}\end{array}$} & \multicolumn{2}{|c|}{$\begin{array}{l}\mathrm{N}_{2} \mathrm{O} /\left(\mathrm{N}_{2} \mathrm{O}+\mathrm{N}_{2}\right) \text { ratio of } \\
\text { cumulative pool-derived } \\
\text { emissions }\end{array}$} & \multicolumn{2}{|c|}{$\begin{array}{l}{ }^{15} \mathrm{~N} \text { recovered in } \\
\mathrm{N}_{2} \mathrm{O}+\mathrm{N}_{2}\end{array}$} \\
\hline & $\left(\mu \mathrm{g} \mathrm{N} \mathrm{kg}{ }^{-1}\right)$ & & $\left(\mu \mathrm{g} \mathrm{N} \mathrm{kg}{ }^{-1}\right)$ & & $\left(\mu \mathrm{g} \mathrm{N} \mathrm{kg}{ }^{-1}\right)$ & & & & $\%$ of added ${ }^{15} \mathrm{~N}$ & \\
\hline Maize S & $643.3 \pm 310.1$ & $\mathrm{a}$ & $4219.0 \pm 3963.6$ & $\mathrm{a}$ & $4830.4 \pm 4235.1$ & $\mathrm{a}$ & $0.16 \pm 0.06$ & n.s. & $0.690 \pm 0.605$ & $\mathrm{a}$ \\
\hline Maize M & $25.3 \pm 40.0$ & $\mathrm{~b}$ & $132.9 \pm 110.9$ & $\mathrm{~b}$ & $159.2 \pm 132.9$ & $\mathrm{~b}$ & $0.15 \pm 0.07$ & n.s. & $0.023 \pm 0.019$ & b \\
\hline Maize L & $15.4 \pm 25.4$ & $\mathrm{~b}$ & $97.7 \pm 96.4$ & $\mathrm{~b}$ & $120.7 \pm 114.8$ & $\mathrm{~b}$ & $0.14 \pm 0.14$ & n.s. & $0.017 \pm 0.016$ & $\mathrm{~b}$ \\
\hline Cup Plant & $31.6 \pm 39.5$ & $\mathrm{~b}$ & $105.5 \pm 101.0$ & $\mathrm{~b}$ & $128.7 \pm 122.0$ & $\mathrm{~b}$ & $0.24 \pm 0.21$ & n.s. & $0.018 \pm 0.017$ & $\mathrm{~b}$ \\
\hline
\end{tabular}

Means and standard deviation for $n=6$. Different letters in one column indicate a significant difference, n.s. indicates no significant difference $(p<0.05)$ between treatments

\footnotetext{
${ }^{15} \mathrm{~N}$ enrichment of $\mathrm{N}$ pools and pool-derived fraction of $\mathrm{N}_{2} \mathrm{O}$
}

Treatments did not exhibit continuous patterns of ap and $\mathrm{Fp}$ values throughout the experiment. The fraction of $\mathrm{N}_{2} \mathrm{O}$ derived from the active labeled $\mathrm{NO}_{3}{ }^{-}$ pool $\left(\mathrm{Fp}_{-} \mathrm{N}_{2} \mathrm{O}\right)$ decreased during the experiment showing that the contribution of $\mathrm{N}_{2} \mathrm{O}$ from sources other than the labeled $\mathrm{NO}_{3}{ }^{-}$pool increased with time (Fig. 2b). Fp_ $\mathrm{N}_{2} \mathrm{O}$ was close to 1.0 in Maize $\mathrm{S}$ for three days after labeling, then decreased to 0.4 on day 5, and ranged between 0.5 and 0.8 until the end of the experiment. For the other treatments, Fp_ $\mathrm{N}_{2} \mathrm{O}$ continuously decreased until day $5 / 6$. After day 6.5, Fp_ $\mathrm{N}_{2} \mathrm{O}$ increased in Maize $\mathrm{M}$ and $\mathrm{L}$, fluctuating between 0.1 and 0.6 . At the last day, Fp_ $\mathrm{N}_{2} \mathrm{O}$ was $<0.07$ in all treatments.

The time course of ${ }^{15} \mathrm{~N}$ enrichment of the active $\mathrm{NO}_{3}{ }^{-}$pool producing $\mathrm{N}_{2} \mathrm{O}$ and $\mathrm{N}_{2}$ (ap_ $\mathrm{N}_{2} \mathrm{O}$, ap_ $\mathrm{N}_{2} \mathrm{O}+$ $\mathrm{N}_{2}$ ) was different in Maize $\mathrm{S}$ than in the other treatments. During the first days after labeling, ${ }^{15} \mathrm{~N}$ enrichment of the active $\mathrm{NO}_{3}{ }^{-}$pool producing $\mathrm{N}_{2} \mathrm{O}$ and $\mathrm{N}_{2}$ (ap_ $\mathrm{N}_{2} \mathrm{O}$, ap_ $\mathrm{N}_{2} \mathrm{O}+\mathrm{N}_{2}$ ) was close to 60 at\% in all treatments (Fig. 3). In Maize S, ap_ $\mathrm{N}_{2} \mathrm{O}$ and ap_ $\mathrm{N}_{2} \mathrm{O}+$ $\mathrm{N}_{2}$ were higher than 50 at\% during the whole experiment and only decreased on the last day. In all other treatments, ap_ $\mathrm{N}_{2} \mathrm{O}$ and ap_ $\mathrm{N}_{2} \mathrm{O}+\mathrm{N}_{2}$ continuously decreased until day 6.5. On day 7, ap-values were higher than 50 at $\%$ and decreased again until the end of the experiment. ${ }^{15} \mathrm{~N}$ enrichment of the total soil $\mathrm{NO}_{3}{ }^{-}$pool $\left({ }^{15} \mathrm{a}_{-} \mathrm{NO}_{3}{ }^{-}\right)$was measured at final harvest and was mostly significantly lower $(p<0.05)$ than ${ }^{15} \mathrm{~N}$ enrichment of the active $\mathrm{NO}_{3}{ }^{-}$pool producing $\mathrm{N}_{2} \mathrm{O}$ and $\mathrm{N}_{2}$ (ap_ $\mathrm{N}_{2} \mathrm{O}$ and ap_ $\mathrm{N}_{2} \mathrm{O}+\mathrm{N}_{2}$ ) from the last gas measurement (Fig. 3, Supplementary table S2).

\section{Soil moisture and its effect on $\mathrm{N}$ fluxes}

Data from soil moisture sensors showed that soil moisture content was higher in Maize S than all other treatments for the first days after labeling (Fig. 4). However, it was lower than the targeted value of $75 \%$ WFPS. As all plants respired large amounts of water, it took a few days to adjust irrigation amounts to plant water demand, and soil moisture could not be kept constant throughout the experiment.

In Maize $\mathrm{S}$ and Cup plant, soil moisture increased with irrigation three days after labeling reaching values around 70\%WFPS. In Maize M and L, soil moisture increased five days after labeling reaching values around 55\%WFPS. In Cup plant, soil moisture stayed on a similar level around $70 \%$ WFPS with fluctuations due to water uptake and irrigation. Although soil moisture was in a similar range in Maize $\mathrm{S}$ and Cup plant from day 4 to 6 and in all maize treatments after day 7, total $\mathrm{N}_{2} \mathrm{O}$ and pool-derived $\mathrm{N}_{2} \mathrm{O}+$ $\mathrm{N}_{2}$ fluxes were always highest in Maize $\mathrm{S}$. Thus, we did not find significant relationships between $\mathrm{N}$ fluxes and soil moisture during the experiment indicating that soil moisture was not the only factor controlling gaseous $\mathrm{N}$ losses (Table 5, supplementary table S3, supplementary figure $\mathrm{S} 1)$. However, the $\mathrm{N}_{2} \mathrm{O} /\left(\mathrm{N}_{2} \mathrm{O}+\mathrm{N}_{2}\right)$ ratio of pool-derived fluxes decreased with increasing soil moisture (\%WFPS, $\operatorname{adj} . \mathrm{R}^{2}=0.14, p<0.05$ ) indicating that increasing soil moisture stimulated $\mathrm{N}_{2} \mathrm{O}$ reduction.

$\mathrm{CO}_{2}$ and ${ }^{13} \mathrm{CO}_{2}$ efflux

The time course of cumulative $\mathrm{CO}_{2}$ efflux and ${ }^{13} \mathrm{C}$ enrichment in $\mathrm{CO}_{2}$ was similar in all treatments (Fig. $5 \mathrm{a}+\mathrm{b}$ ). $\mathrm{CO}_{2}$ efflux was similar in Maize $\mathrm{M}$ and Maize $\mathrm{L}$ where it increased almost linearly during the 
Fig. $3{ }^{15} \mathrm{~N}$ enrichment of the active $\mathrm{N}$ pool undergoing denitrification (ap_ $\mathrm{N}_{2} \mathrm{O}$, ap_ $\mathrm{N}_{2} \mathrm{O}+\mathrm{N}_{2}$ ) and ${ }^{15} \mathrm{~N}$ enrichment of total soil $\mathrm{NO}_{3}{ }^{-}$pool $\left({ }^{15} \mathrm{a}_{-} \mathrm{NO}_{3}{ }^{-}\right)$. Means and standard deviation for $\mathrm{n}=6$. When not visible, error bars are smaller than the symbols

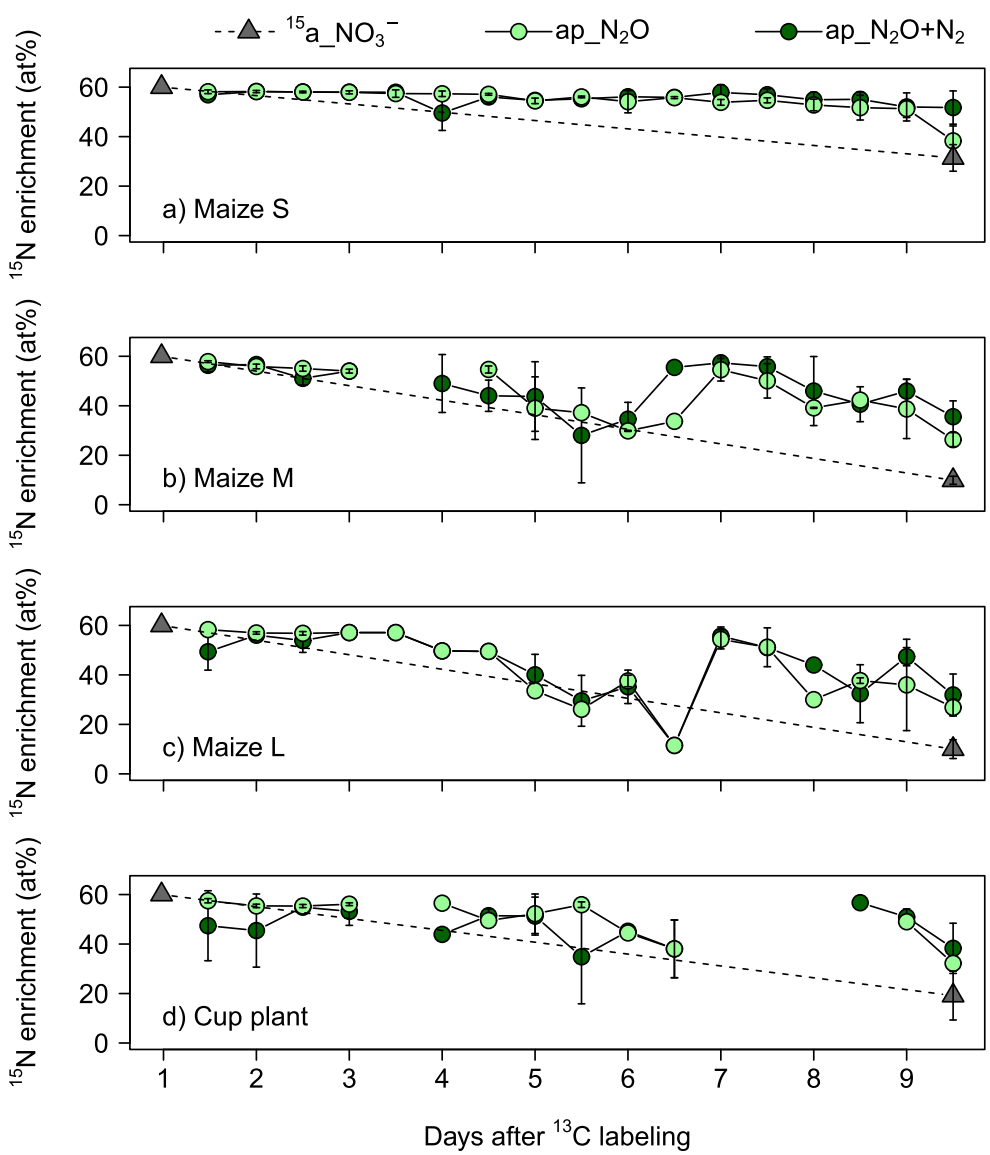

whole experiment, and total cumulative $\mathrm{CO}_{2}$ was only slightly higher in Maize L than in Maize M (Table 4). Lowest cumulative $\mathrm{CO}_{2}$ efflux was measured under Maize S plants where efflux decreased considerably after 1.5 days. Cumulative $\mathrm{CO}_{2}$ efflux under cup plants was significantly lower than from Maize L and not statistically different from the other two maize treatments (Table 4). Overall, cumulative $\mathrm{CO}_{2}$ efflux was positively correlated with root dry matter at final harvest (adj. $\mathrm{R}^{2}=0.36, p<0.01$, Table 5).

${ }^{13} \mathrm{C}$ enrichment in $\mathrm{CO}_{2}$ strongly decreased in all treatments two days after labeling until the end of $\mathrm{CO}_{2}$ sampling (Fig. 5b). Highest ${ }^{13} \mathrm{C}$ enrichment of soil emitted $\mathrm{CO}_{2}$ was measured under Cup plant and lowest in Maize L. It strongly decreased two days after labeling until the end of $\mathrm{CO}_{2}$ sampling. No statistically significant differences $(p<0.05)$ were found in relative ${ }^{13} \mathrm{C}$ recovery in $\mathrm{CO}_{2}$, soil, or soil $+\mathrm{CO}_{2}$ (Table 4 ), but overall, mean relative ${ }^{13} \mathrm{C}$ recovery in soil increased with root dry matter, indicating that root-derived $\mathrm{C}$ recovered in soil increased with root biomass.
Interactions between $\mathrm{N}$ emissions, soil $\mathrm{NO}_{3}{ }^{-}$content, and $\mathrm{C}_{\text {org }}$ availability

Simple linear regression models were tested to identify effects of plant growth, $\mathrm{N}$ uptake, and $\mathrm{C}_{\text {org }}$ availability on cumulative $\mathrm{N}_{2} \mathrm{O}$ and $\mathrm{N}_{2}$ emissions (Table 5, supplementary table $\mathrm{S} 3$ ). Total cumulative $\mathrm{N}_{2} \mathrm{O}$ and pool-derived cumulative $\mathrm{N}_{2} \mathrm{O}+\mathrm{N}_{2}$ emissions were significantly $(p<0.01)$ negatively correlated with root dry matter (adj. $\mathrm{R}^{2}=0.41$ and adj. $\mathrm{R}^{2}=0.32$, respectively) and plant $\mathrm{N}$ uptake (adj. $\mathrm{R}^{2}=0.49$ and adj. $\mathrm{R}^{2}=0.33$, respectively) indicating that gaseous $\mathrm{N}$ losses were highest under plants with small root system and low $\mathrm{N}$ uptake. In addition, total cumulative $\mathrm{N}_{2} \mathrm{O}$ emissions and soil $\mathrm{NO}_{3}{ }^{-}$content at final harvest were positively correlated (adj. $\left.\mathrm{R}^{2}=0.10, p<0.05\right)$. As cumulative $\mathrm{CO}_{2}$ emissions were positively correlated with root dry matter and cumulative $\mathrm{N}$ emissions negatively, total cumulative $\mathrm{N}_{2} \mathrm{O}$ and pool-derived cumulative $\mathrm{N}_{2} \mathrm{O}+\mathrm{N}_{2}$ emissions were negatively correlated with cumulative $\mathrm{CO}_{2}$ efflux (adj. $\mathrm{R}^{2}=0.36, p<0.01$ ). No correlations were found 
Fig. 4 Soil moisture as \% water filled pore space measured with soil moisture sensors $(n=1)$

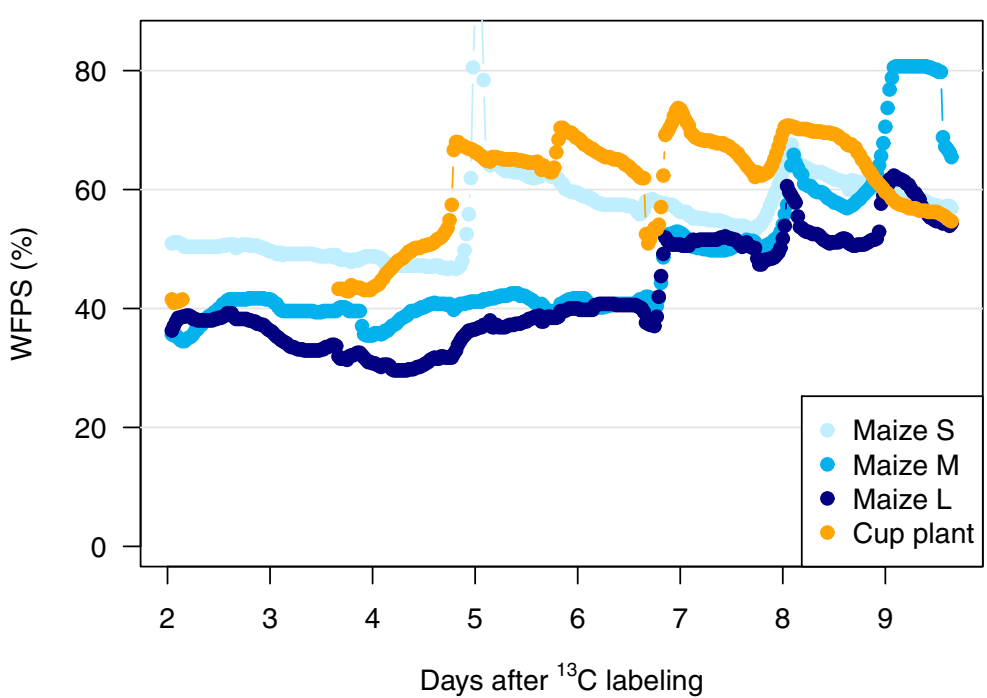

between total or pool-derived cumulative $\mathrm{N}$ emissions or $\mathrm{N}_{2} \mathrm{O} /\left(\mathrm{N}_{2} \mathrm{O}+\mathrm{N}_{2}\right)$ ratio and ${ }^{13} \mathrm{C}$ recovery in soil and/or $\mathrm{CO}_{2}$. However, we identified a weak but significant positive relationship between $\mathrm{N}_{2} \mathrm{O} /\left(\mathrm{N}_{2} \mathrm{O}+\mathrm{N}_{2}\right)$ of poolderived fluxes and $\mathrm{CO}_{2}$ efflux (adj. $\mathrm{R}^{2}=0.11, p<0.01$ ).

\section{Discussion}

Effect of soil moisture and plant $\mathrm{N}$ uptake on $\mathrm{N}_{2} \mathrm{O}$ and $\mathrm{N}_{2}$ emissions

Cumulative $\mathrm{N}$ emissions were $20-40$ times higher in Maize S compared to all other treatments. Plant transpiration strongly affected soil moisture which was highest in Maize $\mathrm{S}$ during the first 4 days after ${ }^{13} \mathrm{C}$ labeling. Soil moisture is an important control of denitrification as it regulates $\mathrm{O}_{2}$ concentration and diffusion in soil (Schlüter et al. 2018, Rohe et al. 2020). Plant roots constantly alter soil moisture and its distribution in soil by root water uptake. Accordingly, previous studies reported that plant growth controlled soil moisture and denitrification rates (Bakken 1988; von Rheinbaben and Trolldenier 1984). In our study, when soil moisture increased with irrigation, $\mathrm{N}_{2} \mathrm{O}$ and, especially, $\mathrm{N}_{2}$ fluxes increased shortly thereafter. Furthermore, the $\mathrm{N}_{2} \mathrm{O}$ / $\left(\mathrm{N}_{2} \mathrm{O}+\mathrm{N}_{2}\right)$ ratio of pool-derived fluxes decreased with increasing soil moisture which is consistent with $\mathrm{N}_{2}$ being the dominant end product of denitrification under high WFPS (Davidson 1991). Although soil moisture was highest in Cup plant from day 4 to 8 , and similar in Maize treatments from day 6 to 9 , N fluxes were highest in Maize $\mathrm{S}$ throughout the experiment. Thus, differences in soil moisture alone cannot explain the vast differences in $\mathrm{N}$ fluxes between Maize $\mathrm{S}$ and the other treatments in our study.

Maize S plants were characterized by lowest root dry matter of all treatments and lower shoot dry matter compared to the other maize treatments. Furthermore, soil $\mathrm{NO}_{3}{ }^{-}$content at final harvest was more than twice as high in Maize $\mathrm{S}$ compared to all other treatments. The relationship between soil $\mathrm{NO}_{3}{ }^{-}$content at the end of the experiment and cumulative $\mathrm{N}_{2} \mathrm{O}$ emissions was weak $(0.10, p<0.05)$. However, $\mathrm{N}$ uptake was negatively correlated with total cumulative $\mathrm{N}_{2} \mathrm{O}$ emissions and pool-derived cumulative $\mathrm{N}_{2} \mathrm{O}+\mathrm{N}_{2}$ emissions (adj. $\mathrm{R}^{2}=0.49, p<0.001$ and adj. $\mathrm{R}^{2}=0.33, p<0.01$, respectively) indicating that $\mathrm{NO}_{3}{ }^{-}$availability played an important role in regulating denitrification. Our results show clearly that an increase in soil moisture led to increasing $\mathrm{N}_{2} \mathrm{O}+\mathrm{N}_{2}$ fluxes, but $\mathrm{N}$ fluxes remained on a low level when $\mathrm{NO}_{3}{ }^{-}$availability was low due to rapid plant $\mathrm{N}$ uptake. Only when both $\mathrm{N}$ and water uptake were low, high $\mathrm{NO}_{3}{ }^{-}$availability and high soil moisture led to strongly increased $\mathrm{N}$ losses.

Effect of nitrate availability and soil moisture on pools and processes contributing to $\mathrm{N}_{2} \mathrm{O}$ formation

Different $\mathrm{NO}_{3}{ }^{-}$pools and $\mathrm{N}$ turnover processes contributed to $\mathrm{N}_{2} \mathrm{O}$ formation throughout the experiment. The ${ }^{15} \mathrm{~N}$ enrichment of the total soil $\mathrm{NO}_{3}{ }^{-}$pool $\left({ }^{15} \mathrm{a}_{-} \mathrm{NO}_{3}{ }^{-}\right)$decreased from 60 at $\%$ after labeling to $10-30$ at $\%$ until the end of the experiment as unlabeled organic $\mathrm{N}$ was 
Fig. 5 Cumulative $\mathrm{CO}_{2}$ efflux from soil (a) and ${ }^{13} \mathrm{C}$ enrichment of $\mathrm{CO}_{2}$ flux from soil (b). Means and standard deviation for $\mathrm{n}=6$. When not visible, error bars are smaller than the symbols
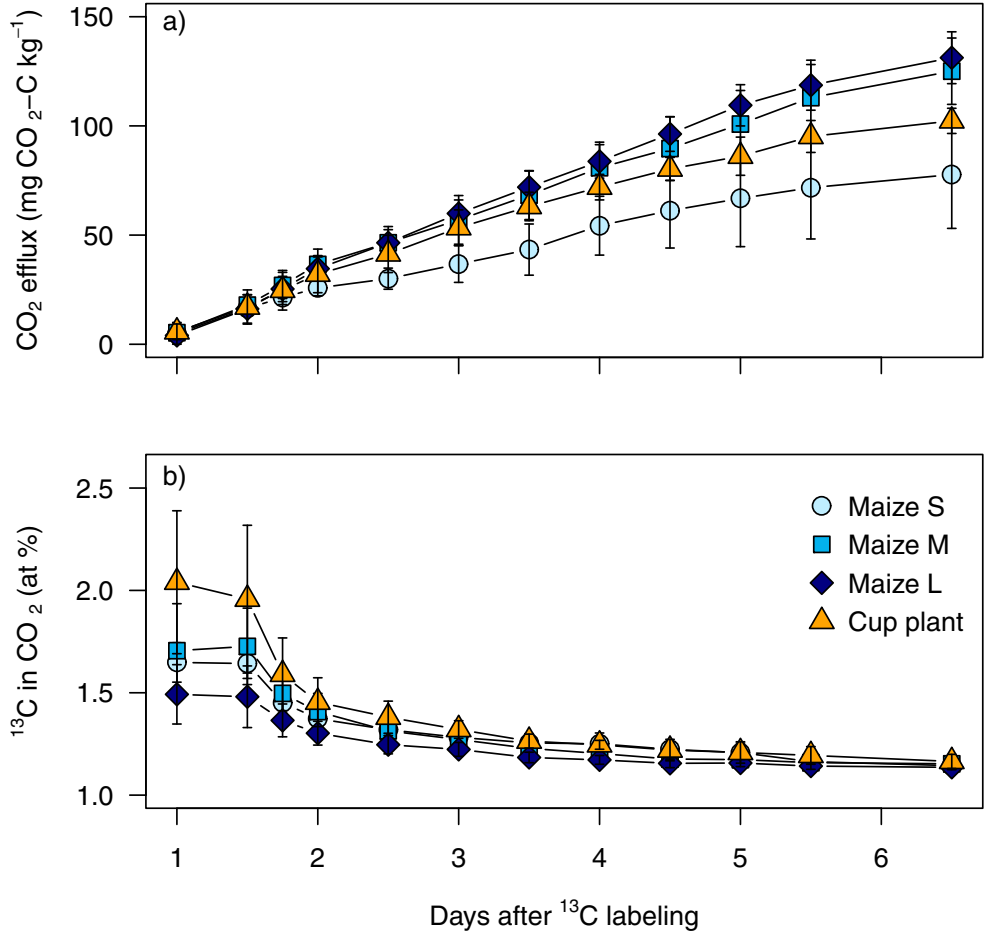

mineralized and diluted the labeled $\mathrm{NO}_{3}{ }^{-}$pool (Buchen et al. 2016; Deppe et al. 2017). Thus, denitrification of unlabeled $\mathrm{NO}_{3}{ }^{-}$, as well as nitrification, nitrifier denitrification, and coupled nitrification-denitrification may have contributed to $\mathrm{N}_{2} \mathrm{O}$ formation (van Groenigen et al. 2015; Wrage-Mönnig et al. 2018; Wrage et al. 2001).

In Maize S, ${ }^{15} \mathrm{a}_{-} \mathrm{NO}_{3}{ }^{-}$at final harvest was significantly higher than in all other treatments, indicating that nitrification was less relevant in this treatment. Accordingly, the fraction of $\mathrm{N}_{2} \mathrm{O}$ derived from the active labeled $\mathrm{NO}_{3}{ }^{-}$pool $\left(\mathrm{Fp}_{-} \mathrm{N}_{2} \mathrm{O}\right.$ ) was $>0.5$ throughout the experiment indicating that most $\mathrm{N}_{2} \mathrm{O}$ was lost through denitrification from labeled $\mathrm{NO}_{3}{ }^{-}$. The ${ }^{15} \mathrm{~N}$ enrichment of the active $\mathrm{NO}_{3}^{-}$pool producing $\mathrm{N}_{2} \mathrm{O}$ and $\mathrm{N}_{2} \mathrm{O}+\mathrm{N}_{2}$ (ap $\mathrm{N}_{2} \mathrm{O}$ and ap $\mathrm{N}_{2} \mathrm{O}+\mathrm{N}_{2}$ ) stayed close to its initial value of 60 at\% highlighting that $\mathrm{N}_{2} \mathrm{O}$ and $\mathrm{N}_{2}$ were mainly lost from anoxic microsites where labeled $\mathrm{NO}_{3}{ }^{-}$had not been diluted by nitrification (Buchen et al. 2016).

In the other treatments, ap_ $\mathrm{N}_{2} \mathrm{O}$, ap_ $\mathrm{N}_{2}$, and $\mathrm{Fp}_{-} \mathrm{N}_{2} \mathrm{O}$ did not exhibit continuous trends. While values first decreased due to dilution with $\mathrm{NO}_{3}{ }^{-}$from nitrification, values increased after day 6.5 (Fig. 3), presumably due to the slight increase in WFPS after irrigation on day 6.5 (Fig. 4). Increasing soil moisture increased denitrification rates in anoxic hotspots, which corresponds with increasing $\mathrm{N}_{2} \mathrm{O}$ and especially $\mathrm{N}_{2}$ fluxes in Maize $\mathrm{M}$ and L. At the same time, it restricted nitrification and thus decreased the share of nitrification-dependent processes

Table 4 Cumulative $\mathrm{CO} 2$ emissions, relative $13 \mathrm{C}$ recovery in soil and $\mathrm{CO} 2$

\begin{tabular}{|c|c|c|c|c|c|c|c|c|}
\hline & \multicolumn{2}{|c|}{ Cumulative $\mathrm{CO}_{2}$} & \multicolumn{2}{|c|}{ relative ${ }^{13} \mathrm{C}$ recovery in $\mathrm{CO}_{2}$} & \multicolumn{2}{|c|}{ relative ${ }^{13} \mathrm{C}$ recovery in soil } & \multicolumn{2}{|c|}{ relative ${ }^{13} \mathrm{C}$ recovery in soil $+\mathrm{CO}_{2}$} \\
\hline & $\left(\mathrm{mg} \mathrm{C} \mathrm{kg}^{-1}\right)$ & & (\% of recov & & (\% of recov & & (\% of recove & \\
\hline Maize S & $77.7 \pm 24.6$ & $\mathrm{c}$ & $4.24 \pm 1.16$ & n.s. & $0.57 \pm 3.11$ & n.s. & $4.81 \pm 3.72$ & n.s. \\
\hline Maize M & $125.0 \pm 15.2$ & $a b$ & $5.83 \pm 3.34$ & n.s. & $1.11 \pm 5.71$ & n.s. & $6.94 \pm 3.73$ & n.s. \\
\hline Maize L & $131.2 \pm 11.9$ & $\mathrm{a}$ & $3.73 \pm 1.38$ & n.s. & $3.37 \pm 1.62$ & n.s. & $7.10 \pm 1.62$ & n.s. \\
\hline Cup Plant & $102.3 \pm 5.8$ & $\mathrm{bc}$ & $4.57 \pm 1.83$ & n.s. & $2.13 \pm 1.37$ & n.s. & $6.70 \pm 1.87$ & n.s. \\
\hline
\end{tabular}

Mean and standard deviation for $\mathrm{n}=6$. Different letters in one column indicate a significant difference, n.s. indicates no significant difference $(p<0.05)$ between treatments 
Table 5 Results of simple linear regressions between parameters

\begin{tabular}{|c|c|c|c|c|}
\hline response & predictor & adjusted $\mathrm{R}^{2}$ & $p$-value & $\mathrm{n}$ \\
\hline total $\mathrm{N}_{2} \mathrm{O}$ flux & $\mathrm{CO}_{2}$ flux & -0.0136 & 0.8788 & 74 \\
\hline pool-derived $\mathrm{N}_{2} \mathrm{O}+\mathrm{N}_{2}$ flux & $\mathrm{CO}_{2}$ flux & 0.0157 & 0.1458 & 74 \\
\hline mean total $\mathrm{N}_{2} \mathrm{O}$ flux & $\%$ water-filled pore space & -0.0252 & 0.9179 & 35 \\
\hline mean pool-derived $\mathrm{N}_{2} \mathrm{O}+\mathrm{N}_{2}$ flux & $\%$ water-filled pore space & -0.0158 & 0.5111 & 35 \\
\hline $\mathrm{N}_{2} \mathrm{O} /\left(\mathrm{N}_{2} \mathrm{O}+\mathrm{N}_{2}\right)$ ratio (pool-derived) & $\%$ water-filled pore space & 0.1365 & 0.01402 & 35 \\
\hline Cumulative $\mathrm{CO}_{2}$ & DM Root 2nd harvest & 0.3574 & 0.00121 & 24 \\
\hline Total cumulative $\mathrm{N}_{2} \mathrm{O}$ & DM Root 2nd harvest & 0.4090 & 0.00046 & 24 \\
\hline Pool-derived cumulative $\mathrm{N}_{2} \mathrm{O}+\mathrm{N}_{2}$ & DM Root 2nd harvest & 0.3210 & 0.00231 & 24 \\
\hline Total cumulative $\mathrm{N}_{2} \mathrm{O}$ & Plant $\mathbf{N}$ uptake & 0.4894 & $8.5 \times 10^{-05}$ & 24 \\
\hline Pool-derived cumulative $\mathrm{N}_{2} \mathrm{O}+\mathrm{N}_{2}$ & Plant $\mathrm{N}$ uptake & 0.3300 & 0.00197 & 24 \\
\hline Total cumulative $\mathrm{N}_{2} \mathrm{O}$ & Soil $\mathrm{NO}_{3}{ }^{-}$content 2 nd harvest & 0.0983 & 0.0477 & 24 \\
\hline Pool-derived cumulative $\mathrm{N}_{2} \mathrm{O}+\mathrm{N}_{2}$ & Soil $\mathrm{NO}_{3}{ }^{-}$content 2 nd harvest & 0.0131 & 0.2656 & 24 \\
\hline Total cumulative $\mathrm{N}_{2} \mathrm{O}$ & cumulative $\mathrm{CO}_{2}$ & 0.3573 & 0.00121 & 24 \\
\hline Pool-derived cumulative $\mathrm{N}_{2} \mathrm{O}+\mathrm{N}_{2}$ & cumulative $\mathrm{CO}_{2}$ & 0.3641 & 0.00107 & 24 \\
\hline Total cumulative $\mathrm{N}_{2} \mathrm{O}$ & recovered ${ }^{13} \mathrm{C}$ in soil $+\mathrm{CO}_{2}$ & -0.0068 & 0.3683 & 24 \\
\hline Pool-derived cumulative $\mathrm{N}_{2} \mathrm{O}+\mathrm{N}_{2}$ & recovered ${ }^{13} \mathrm{C}$ in soil $+\mathrm{CO}_{2}$ & 0.0051 & 0.302 & 24 \\
\hline $\mathrm{N}_{2} \mathrm{O} /\left(\mathrm{N}_{2} \mathrm{O}+\mathrm{N}_{2}\right.$ ) ratio (pool-derived) & recovered ${ }^{13} \mathrm{C}$ in soil $+\mathrm{CO}_{2}$ & -0.0389 & 0.7138 & 24 \\
\hline
\end{tabular}

Significant regressions $(p \leq 0.05)$ are marked in bold

contributing to $\mathrm{N}_{2} \mathrm{O}$ formation (reflected in increasing Fp_ $\mathrm{N}_{2} \mathrm{O}$ ). Simultaneously increasing ap_ $\mathrm{N}_{2} \mathrm{O}$ and ap_ $\mathrm{N}_{2} \mathrm{O}+\mathrm{N}_{2}$ in Maize $\mathrm{M}$ and $\mathrm{L}$ on Day 7 indicate that ${ }^{15} \overline{\mathrm{N}}$ enrichment of the active labeled $\mathrm{NO}_{3}{ }^{-}$pool was still close to 60 at $\%$ in microsites where denitrification took place. The rise of actual ap-values back towards initial values is in line with a change in the anaerobic volume where denitrification occurs (Bergstermann et al. 2011). A recent study conducted with the same soil but without plants showed that $\mathrm{O}_{2}$ concentration in repacked soil cores was highly variable and average $\mathrm{O}_{2}$ saturation decreased with increasing soil moisture while the anaerobic soil volume fraction increased with increasing soil moisture and soil depth (Rohe et al. 2020). After day 6.5, $\mathrm{N}_{2} \mathrm{O}+\mathrm{N}_{2}$ were predominately lost from domains that had been continuously anoxic or were most distant from oxic domains and thus were less diluted with unlabeled $\mathrm{NO}_{3}{ }^{-}$. We anticipate that in these microsites $\mathrm{O}_{2}$ concentrations had been low enough to prevent nitrification during the first days so that the labeled pool was not diluted by unlabeled $\mathrm{NO}_{3}{ }^{-}$from nitrification.

While fungal co-denitrification has been reported as the dominant $\mathrm{N}_{2} \mathrm{O}$ source in a planted soil with high $\mathrm{NO}_{3}{ }^{-}$content (Laughlin and Stevens 2002), our data provide no indications for co-denitrification, because ap_ $\mathrm{N}_{2} \mathrm{O}$ and ap_ $\mathrm{N}_{2} \mathrm{O}+\mathrm{N}_{2}$ were always higher than
${ }^{15} \mathrm{a}_{-} \mathrm{NO}_{3}{ }^{-}$, but co-denitrification would lead to ap lower than ${ }^{-15} \mathrm{a}_{-} \mathrm{NO}_{3}{ }^{-}$due to hybrid formation of $\mathrm{N}_{2} \mathrm{O}$ or $\mathrm{N}_{2}$ (Spott and Stange 2007).

Thus, in our study, $\mathrm{N}_{2} \mathrm{O}$ and $\mathrm{N}_{2}$ fluxes mainly derived from denitrification of labeled ${ }^{15} \mathrm{NO}_{3}{ }^{-}$in anoxic microsites, while nitrification simultaneously occurred in more oxic parts of the soil, potentially contributing to formation of unlabeled $\mathrm{N}_{2} \mathrm{O}$.

\section{Effect of root-derived $\mathrm{C}$ on $\mathrm{N}$ emissions}

One of the core hypotheses of this study was that availability of root-derived $\mathrm{C}$ is a key driver of denitrification in planted soils. It was based on a number of studies reporting higher denitrification activity in rhizosphere compared to bulk soil which was explained by higher soil C (Hamonts et al. 2013; Klemedtsson et al. 1987; Malique et al. 2019 ; Smith and Tiedje 1979). Detectable rhizodeposition and $\mathrm{C}$ flow into belowground respiration result from $\mathrm{C}$ translocation from shoots to roots (Remus and Augustin 2016). Thus, we used ${ }^{13} \mathrm{CO}_{2}$ pulse labeling to trace $\mathrm{C}$ translocation from shoots to roots, its release by roots into the soil, and ${ }^{13} \mathrm{CO}_{2}$ emitted from soil.

We found a positive correlation between root dry matter at final harvest and cumulative $\mathrm{CO}_{2}$ efflux 
(adj. $\left.\mathrm{R}^{2}=0.36, p<0.01\right)$ and, on average, relative ${ }^{13} \mathrm{C}$ recovery in soil increased with increasing root dry matter indicating that root exudation increased with root dry matter. However, we could not detect any relationship between total or pool-derived $\mathrm{N}$ fluxes and total $\mathrm{CO}_{2}$ efflux or root-derived $\mathrm{C}$ and cumulative $\mathrm{N}$ emissions or the ratio of gaseous products.

Most previous studies investigating plant effects on denitrification did not measure $\mathrm{N}_{2} \mathrm{O}$ and $\mathrm{N}_{2}$ emissions under growing plants, but either potential denitrification (Klemedtsson et al. 1987; Malique et al. 2019; Smith and Tiedje 1979) or denitrification capacity (Hamonts et al. 2013) from soil samples taken from rhizosphere and/or bulk soil. In those studies, conducted under anoxic conditions with unlimited $\mathrm{NO}_{3}{ }^{-}$ supply, higher $\mathrm{C}$ availability in rhizosphere soil samples led to higher emissions of $\mathrm{N}_{2} \mathrm{O}$ and $\mathrm{N}_{2}$. However, when separation of bulk soil and rhizosphere was not well-defined due to densely rooted soil in pots, no differences in potential denitrification were found (Malique et al. 2019). In the few studies with growing plants, higher denitrification rates were measured during the first weeks after emergence (Senbayram et al. 2020), with poorly growing plants (von Rheinbaben and Trolldenier 1984), or when root biomass was decreasing (Haider et al. 1987). No stimulation of denitrification was found when actively growing maize plants were compared to unplanted soil (Haider et al. 1985). Accordingly, root-derived $\mathrm{C}$ may stimulate denitrification when soil $\mathrm{NO}_{3}{ }^{-}$is not limited. We were not able to estimate the effect of $\mathrm{C}$ availability on denitrification as $\mathrm{NO}_{3}{ }^{-}$limitation and $\mathrm{O}_{2}$ inhibition were the factors controlling denitrification in our study.

Plant root effects on denitrification

The activity of denitrifying microorganisms in soil is primarily controlled by availability of $\mathrm{O}_{2}, \mathrm{NO}_{3}{ }^{-}$, and $\mathrm{C}_{\text {org }}$ (proximal factors, Groffman et al. 1988). Plant roots affect these through rhizodeposition, root respiration, $\mathrm{N}$ and water uptake (distal factors, Groffman et al. 1988). Figure 6 shows how proximal and distal factors change during plant and root growth and how these
Fig. 6 Conceptual drawing of plant root effects (distal factors, green/grey) on drivers of denitrification (proximal factors, light grey) and potential $\mathrm{N}_{2} \mathrm{O}+$ $\mathrm{N}_{2}$ losses (orange/dark grey). Based on two assumptions: (i) $\mathrm{NO}_{3}{ }^{-}$-based fertilizer is only added before plant growth and (ii) root water uptake is the main regulator of soil moisture

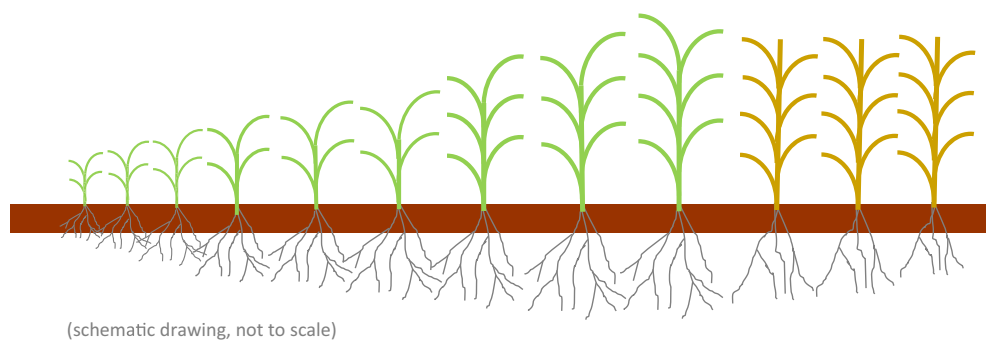

Rhizodeposition

$\mathrm{C}_{\text {org }}$ availability

Root respiration

$\mathrm{O}_{2}$ availability in rhizosphere
$\mathrm{NO}_{3}{ }^{-}$availability
Water uptake

Soil moisture 
affect denitrification in planted soil. The presented conceptual drawing is based on two assumptions: (i) $\mathrm{NO}_{3}{ }^{-}$ based fertilizer is only added before plant growth and (ii) root water uptake is the main regulator of soil moisture.

In most agricultural soils, available $\mathrm{C}_{\text {org }}$ is low. With increasing root growth, rhizodeposition and root turnover increase $C_{\text {org }}$ availability. At the same time, root respiration and microbial activity increase, decreasing $\mathrm{O}_{2}$ concentrations in the rhizosphere. This offers favorable conditions for denitrifying microorganisms as long as sufficient $\mathrm{NO}_{3}{ }^{-}$is available (Klemedtsson et al., 1987; Senbayram et al., 2020; Stefanson, 1972). As N uptake increases with plant and root growth, $\mathrm{NO}_{3}{ }^{-}$ becomes limited for denitrifiers (Haider et al., 1985). Furthermore, increasing water uptake decreases soil moisture and restricts formation of anoxic microsites for denitrification (Bakken 1988, von Rheinbaben and Trolldenier, 1984). Accordingly, our study showed that with increasing plant and root growth, plant water and $\mathrm{N}$ uptake became the most important controls of denitrification. Similarly, soil moisture can vary strongly under field conditions depending on precipitation and plant water uptake. When $\mathrm{NO}_{3}{ }^{-}$is available (i.e. after fertilization), increasing soil moisture after rainfall can lead to strongly increased $\mathrm{N}_{2} \mathrm{O}+\mathrm{N}_{2}$ emissions (Buchen et al. 2017, Ruser et al. 2017).

Overall, plants continuously change boundary conditions and substrate availability for denitrification in soil, and it requires high technical input and equipment to keep experimental conditions stable and controlled. However, as plants do control these conditions so strongly, it is very exciting and very important to further investigate these processes to understand and predict $\mathrm{N}$ cycling, denitrification, and gaseous $\mathrm{N}$ losses on the field scale. Further research is thus indispensable.

\section{Conclusions}

We aimed to investigate how plants control the main substrates for denitrification $\left(\mathrm{NO}_{3}{ }^{-}\right.$and $\left.\mathrm{C}_{\text {org }}\right)$ through $\mathrm{N}$ uptake and root exudation. To our knowledge, this is the first study combining in situ measurements of $\mathrm{N}_{2} \mathrm{O}+\mathrm{N}_{2}$ fluxes with estimations of root-derived $\mathrm{C}$ availability.

Plant water uptake was a main factor controlling soil moisture and, thus, daily $\mathrm{N}_{2} \mathrm{O}+\mathrm{N}_{2}$ fluxes, cumulative $\mathrm{N}$ emissions, and $\mathrm{N}_{2} \mathrm{O}$ production pathways. However, $\mathrm{N}$ fluxes remained on a low level when $\mathrm{NO}_{3}{ }^{-}$availability was low due to rapid plant $\mathrm{N}$ uptake. Only when both $\mathrm{N}$ and water uptake were low, high $\mathrm{NO}_{3}{ }^{-}$availability and high soil moisture led to strongly increased $\mathrm{N}$ losses. Our study provides evidence that most $\mathrm{N}$ losses originated from denitrification in small anoxic hotspots where $\mathrm{NO}_{3}{ }^{-}$was not diluted by nitrification. Simultaneously occurring nitrification in oxic parts of the soil potentially contributed to formation of unlabeled $\mathrm{N}_{2} \mathrm{O}$.

Total $\mathrm{CO}_{2}$ efflux was positively correlated with root dry matter, but there was no indication of any relationship between recovered ${ }^{13} \mathrm{C}$ from root exudation and cumulative $\mathrm{N}$ emissions. We anticipate that higher $\mathrm{C}_{\text {org }}$ availability in pots with large root systems did not lead to higher denitrification rates, as $\mathrm{NO}_{3}^{-}$was limiting denitrification due to plant $\mathrm{N}$ uptake. Overall, we conclude that root-derived $\mathrm{C}$ stimulates denitrification only when soil $\mathrm{NO}_{3}{ }^{-}$is not limited and low $\mathrm{O}_{2}$ concentrations enable denitrification.

Acknowledgements The authors thank Simone Urstadt, Finn Malinowski, Bridith Angulo Schipper, Ilse Thaufelder, and Jakob Streuber for help during experimental and laboratory work. We are thankful to Tomor Krasniqi for weighing endless numbers of C:N samples and to the Centre for Stable Isotope Research and Analysis of the University of Göttingen for analysis of $\mathrm{C}$ and $\mathrm{N}$ isotopes of soil and plant samples. Further, we thank Dr. Daniel Ziehe and Kerstin Gilke for GC analyses, Dr. Anette Giesemann and Martina Heuer for IRMS analyses of gas samples, and Dr. Wolfram Eschenbach for analysis of ${ }^{15} \mathrm{~N}_{\text {in }} \mathrm{NO}_{3}{ }^{-}$and $\mathrm{NH}_{4}{ }^{+}$. We thank Prof. Dr. Jürgen Böttcher for soil classification and Prof. Kenneth Albrecht and Dr. Pedro Gerstberger for supplying cup plant seedlings. We thank Dr. Bernd Steingrobe for his feedback on the manuscript. Furthermore, we acknowledge two anonymous reviewers for their advice to improve the quality of the manuscript.

Funding Open Access funding enabled and organized by Projekt DEAL. This study was funded by the Deutsche Forschungsgemeinschaft (DFG, German Research Foundation) through the research unit DFG-FOR 2337 (DI 546/4-1, We 1904/10 - 2): Denitrification in Agricultural Soils: Integrated Control and Modelling at Various Scales (DASIM).

Open Access This article is licensed under a Creative Commons Attribution 4.0 International License, which permits use, sharing, adaptation, distribution and reproduction in any medium or format, as long as you give appropriate credit to the original author(s) and the source, provide a link to the Creative Commons licence, and indicate if changes were made. The images or other third party material in this article are included in the article's Creative Commons licence, unless indicated otherwise in a credit line to the material. If material is not included in the article's Creative Commons licence and your intended use is not permitted by statutory regulation or exceeds the permitted use, you will need to obtain permission directly from the copyright holder. To view a copy of this licence, visit http://creativecommons.org/licenses/by/4.0/. 


\section{References}

Bakken LR (1988) Denitrification under different cultivated plants: effects of soil moisture tension, nitrate concentration, and photosynthetic activity. Biol Fertil Soils 6:271-278

Bergstermann A, Cárdenas L, Bol R, Gilliam L, Goulding K, Meijide A, Scholefield D, Vellejo A, Well R (2011) Effect of antecedent soil moisture conditions on emissions and isotopologue distribution of $\mathrm{N}_{2} \mathrm{O}$ during denitrification. Soil Biol Biochem 43:240-250. https://doi.org/10.1016/j. soilbio.2010.10.003

Buchen C, Lewicka-Szczebak D, Fuß R, Helrich M, Flessa H, Well R (2016) Fluxes of $\mathrm{N}_{2}$ and $\mathrm{N}_{2} \mathrm{O}$ and contributing processes in summer after grassland renewal and grassland conversion to maize cropping on a Plaggic Anthrosol and a Histic Gleysol. Soil Biol Biochem 101:6-19. https://doi. org/10.1016/j.soilbio.2016.06.028

Buchen C, Well R, Helfrich M, Fuß R, Kayser M, Gensior A, Benke M, Flessa $\mathrm{H}$ (2017) Soil mineral $\mathrm{N}$ dynamics and $\mathrm{N}_{2} \mathrm{O}$ emissions following grassland renewal. Agric Ecosyst Environ 246:325-342. https://doi.org/10.1016/j. agee.2017.06.013

Burford JR, Bremner JM (1975) Relationships between the denitrification capacities of soils and total, water-soluble and readily decomposable soil organic matter. Soil Biol Biochem 7:389-394. https://doi.org/10.1016/0038-0717(75 )90055-3

Carvalhais LC, Dennis PG, Fedoseyenko D, Hajirezaei MR, Borriss R, von Wirén N (2011) Root exudation of sugars, amino acids, and organic acids by maize as affected by nitrogen, phosphorus, potassium, and iron deficiency. J Plant Nutr Soil Sci 174:3-11. https://doi.org/10.1002 /jpln.201000085

Chantigny MH, Angers DA, Kaiser K, Kalbitz K (2007) Extraction and characterization of dissolved organic matter. In: Carter MR, Gregorich DG (ed) Soil sampling and methods of analysis, 2nd edn, Taylor \& Francis Group, Abingdon

Cheng W, Coleman DC, Carroll CR, Hoffman CA (1993) In situ measurement of root respiration and soluble $\mathrm{C}$ concentrations in the rhizosphere. Soil Biol Biochem 25:1189-1196. https://doi.org/10.1016/0038-0717(93)90214-V

Davidson EA (1991) Fluxes of nitrous oxide and nitric oxide from terrestrial ecosystems. In: Rogers JE, Whitman WB (eds) Microbial production and consumption of greenhouse gases: methane, nitrogen oxides and halomethanes. American Society for Microbiology, Washington (DC), pp 219-235

Deppe M, Well R, Giesemann A, Spott O, Flessa H (2017) Soil $\mathrm{N}_{2} \mathrm{O}$ fluxes and related processes in laboratory incubations simulating ammonium fertilizer depots. Soil Biol Biochem 104:68-80. https://doi.org/10.1016/j.soilbio.2016.10.005

Eschenbach W, Lewicka-Szczebak D, Stange CF, Dyckmans J, Well R (2017) Measuring ${ }^{15} \mathrm{~N}$ abundance and concentration of aqueous nitrate, nitrite, and ammonium by membrane inlet quadrupole mass spectrometry. Anal Chem 89:6076-6081. https://doi.org/10.1021/acs.analchem.7b00724

Eschenbach W, Well R, Dyckmans J (2018) NO reduction to $\mathrm{N}_{2} \mathrm{O}$ improves nitrate ${ }^{15} \mathrm{~N}$ abundance analysis by membrane inlet quadrupole mass spectrometry. Anal Chem 90:1121611218. https://doi.org/10.1021/acs.analchem.8b02956
Firestone MK, Smith MS, Firestone RB, Tiedje JM (1979) The influence of nitrate, nitrite, and oxygen on the composition of the gaseous products of denitrification in soil. Soil Sci Soc Am J 43:1140-1144

Gansberger P, Montgomery LFR, Liebhard P (2015) Botanical characteristics, crop management and potential of Silphium perfoliatum $\mathrm{L}$. as a renewable resource for biogas production: A review. Ind Crop Prod 63:362-372

Gransee A, Wittenmayer L (2000) Qualitative and quantitative analysis of water-soluble root exudates in relation to plant species and development. J Plant Nutr Soil Sci 163:381-385

Groffman PM, Tiedje JM, Robertson GP, Christensen S (1988) Denitrification at different temporal and geographical scales: proximal and distal controls. In: Wilson JR (ed) Advances in nitrogen cycling in agricultural ecosystems. CAB International, Wallingford, pp 174-192

Groffman PM, Altabet MA, Böhlke JK, Butterbach-Bahl K, David MB, Firestone MK, Giblin AE, Kana TM, Nielsen LP, Voytek MA (2006) Methods for measuring denitrification: Diverse approaches to a difficult problem. Ecol Appl 16: 2091-2122. https://doi.org/10.1890/1051-0761(2006)016 [2091:MFMDDA]2.0.CO;2

Haider K, Mosier A, Heinemeyer O (1985) Phytotron experiments to evaluate the effect of growing plants on denitrification. Soil Sci Soc Am J 49:636-641

Haider K, Mosier A, Heinemeyer O (1987) The effect of growing plants on dentrification at high soil nitrate concentrations. Soil Sci Soc Am J 51:97-102

Hamonts K, Clough TJ, Stewart A, Clinton PW, Richardson AE, Wakelin AE, O'Callaghan M, Condron LM (2013) Effect of nitrogen and waterlogging on denitrifier gene abundance, community structure and activity in the rhizosphere of wheat. FEMS Microbiol Ecol 83:568-584. https://doi.org/10.1111 /1574-6941.12015

Hauck RD, Melsted SW (1956) Some aspects of the problem of evaluating denitrification in soils. Soil Sci Soc Am J 20:361364. https://doi.org/10.2136/sssaj1956.03615995 $002000030017 \mathrm{x}$

Husáková I, Weiner J, Münzbergová Z (2018) Species traits and shoot-root biomass allocation in 20 dry-grassland species. $\mathrm{J}$ Plant Ecol 11:273-285. https://doi.org/10.1093/jpe/rtw143

Klemedtsson L, Svensson BH, Rosswall T (1987) Dinitrogen and nitrous oxide produced by denitrification and nitrification in soil with and without barley plants. Plant Soil 99:303-319. https://doi.org/10.1007/BF02370877

Kuzyakov Y, Domanski G (2000) Carbon input by plants into the soil. Review. J Plant Nutr Soil Sci 163:421-431. https://doi. org/10.1002/1522-2624(200008)163:4<421::AID-JPLN421 $>3.0 . \mathrm{CO} ; 2-\mathrm{R}$

Laughlin RJ, Stevens RJ (2002) Evidence for fungal dominance of denitrification and codenitrification in a grassland soil. Soil Sci Soc Am J 66:1540-1548. https://doi.org/10.2136 /sssaj2002.1540

Lewicka-Szczebak D, Well R, Giesemann A, Rohe L, Wolf U (2013) An enhanced technique for automated determination of ${ }^{15} \mathrm{~N}$ signatures of $\mathrm{N}_{2},\left(\mathrm{~N}_{2}+\mathrm{N}_{2} \mathrm{O}\right)$ and $\mathrm{N}_{2} \mathrm{O}$ in gas samples. Rapid Commun Mass Spectrom 27:1548-1558. https://doi. org/10.1002/rcm.6605

Lewicka-Szczebak D, Augustin J, Giesemann A, Well R (2017) Quantifying $\mathrm{N}_{2} \mathrm{O}$ reduction to $\mathrm{N}_{2}$ based on $\mathrm{N}_{2} \mathrm{O}$ isotopocules-validation with independent methods (helium 
incubation and ${ }^{15} \mathrm{~N}$ gas flux method). Biogeosciences 14: 711-732. https://doi.org/10.5194/bg-14-711-2017

Malhi SS, Johnston AM, Schoenau JJ, Wang ZH, Vera CL (2011) Seasonal biomass accumulation and nutrient uptake of wheat, barley and oat on a Black Chernozem Soil in Saskatchewan. Can J Plant Sci 86:1005-1014. https://doi.org/10.4141/p05-116

Malique F, Ke P, Böttcher J, Dannenman M, Butterbach-Bahl K (2019) Interactive plant and soil effects on denitrification potential in agricultural soils. Plant Soil 20:6603

Nguyen C (2003) Rhizodeposition of organic C by plants: mechanisms and controls. Agronomie 23:375-396. https://doi. org/10.1051/agro:2003011

Novák V, Vidovič J (2003) Transpiration and nutrient uptake dynamics in maize (Zea mays L.). Ecol Modell 166:99107. https://doi.org/10.1016/S0304-3800(03)00102-9

Paterson E, Sim A (1999) Rhizodeposition and C-partitioning of Lolium perenne in axenic culture affected by nitrogen supply and defoliation. Plant Soil 216:155-164. https://doi. org/10.1023/A:1004789407065

Pausch J, Kuzyakov Y (2018) Carbon input by roots into the soil: Quantification of rhizodeposition from root to ecosystem scale. Glob Chang Biol 24:1-12. https://doi.org/10.1111 /gcb. 13850

Philippot L, Hallin S, Börjesson G, Baggs EM (2009) Biochemical cycling in the rhizosphere having an impact on global change. Plant Soil 321:61-81. https://doi.org/10.1007 /s11104-008-9796-9

R Core Team (2019) R: A Language and Environment for Statistical Computing

Remus R, Augustin J (2016) Dynamic linking of ${ }^{14} \mathrm{C}$ partitioning with shoot growth allows a precise determination of plantderived C input to soil. Plant Soil 408:493-513. https://doi. org/10.1007/s11104-016-3006-y

Rohe L, Apelt B, Vogel HJ, Well R, Wu GM, Schlüter S (2020) Denitrification in soil as a function of oxygen supply and demand at the microscale. Biogeosci Discuss. https://doi. org/10.5194/bg-2020-221 (in review)

Ruser R, Fuß R, Andres M, Hegewald H, Kesenheimer K, Köbke S, Räbiger T, Quinones TS, Augustin J, Christen O, Dittert K, Kage H, Lewandowski I, Prochnow A, Stichnothe H, Flessa H (2017) Nitrous oxide emissions from winter oilseed rape cultivation. Agric Ecosyst Environ 249:57-69. https://doi.org/10.1016/j.agee.2017.07.039(2017)

Schlüter S, Henjes S, Zawallich J, Bergaust L, Horn M, Ippisch O, Vogel HJ, Dörsch P (2018) Denitrification in soil aggregate analogues-effect of aggregate size and oxygen diffusion. Front Environ Sci 6:1-10. https://doi.org/10.3389 /fenvs.2018.00017

Scholefield D, Hawkins JMBB, Jackson SM (1997) Development of a helium atmosphere soil incubation technique for direct measurement of nitrous oxide and dinitrogen fluxes during denitrification. Soil Biol Biochem 29:1345-1352. https://doi. org/10.1016/S0038-0717(97)00021-7

Senbayram M, Well R, Shan J, Bol R, Burkart S, Jones DL, Wu D (2020) Rhizosphere processes in nitrate-rich barley soil tripled both $\mathrm{N}_{2} \mathrm{O}$ and $\mathrm{N}_{2}$ losses due to enhanced bacterial and fungal denitrification. Plant Soil. https://doi.org/10.1007 /s11104-020-04457-9

Smith MS, Tiedje JM (1979) The effect of roots on soil denitrification. Soil Sci Soc Am J 43:951-955
Spott O, Stange CF (2007) A new mathematical approach for calculation the contribution of anammox, denitrification and atmosphere to an $\mathrm{N}_{2}$ mixture based on a ${ }^{15} \mathrm{~N}$ tracer technique. Rapid Commun Mass Spectrom 21:2398-2406. https://doi. org/10.1002/rcm

Spott O, Russow R, Apelt B, Stange CF (2006) A ${ }^{15} \mathrm{~N}$-aided artificial atmosphere gas flow technique for online determination of soil $\mathrm{N}_{2}$ release using the zeolite Köstrohlith SX6. Rapid Commun Mass Spectrom 20:3267-3274. https://doi. org/10.1002/rcm

Stefanson RC (1972) Soil denitrification in sealed soil-plant systems I. Effect of plants, soil water content and soil organic matter content. Plant Soil 127:113-127

van Groenigen JW, Huygens D, Boeckx P, Kuyper ThW, Lubbers IM, Rütting T, Groffman PM (2015) The soil N cycle: New insights and key challenges. Soil 1:235-256. https://doi. org/10.5194/soil-1-235-2015

Vancura V (1964) Root exudates of plants I. Analysis of root exudates of barley and wheat in their initial phases of growth. Plant Soil 21:231-248. https://doi.org/10.1007/BF02139643

Vancura V, Hovadik A (1965) Root exudates of plants II. Composition of root exudates of some vegetables. Plant Soil 22:21-32

Vinther FP (1984) Total denitrification and the ratio between $\mathrm{N}_{2} \mathrm{O}$ and $\mathrm{N}_{2}$ during the growth of spring barley. Plant Soil 76:227232. https://doi.org/10.1007/BF02205582

von Rheinbaben W, Trolldenier G (1984) Influence of plant growth on denitrification in relation to soil moisture and potassium nutrition. Zeitschrift für Pflanzenernärung Bodenkd 147:730-738. https://doi.org/10.1002 /jpln.19841470610

Well R, Myrold DD (1999) Laboratory evaluation of a new method for in situ measurement of denitrification in watersaturated soils. Soil Biol Biochem 31:1109-1119. https://doi. org/10.1016/S0038-0717(99)00029-2

Wrage N, Velthof GL, van Beusichem ML, Oenema O (2001) The role of nitrifier denitrification in the production of nitrous oxide. Soil Biol Biochem 33:1723-1732. https://doi. org/10.1016/S0038-0717(01)00096-7

Wrage-Mönnig N, Horn MA, Well R, Müller C, Velthof G, Oenema O (2018) The role of nitrifier denitrication in the production of nitrous oxide revisited. Soil Biol Biochem 123: A3-A16. https://doi.org/10.1016/j.soilbio.2018.03.020

Wu H, Dannenmann M, Fanselow N, Wolf B, Yao Z, Wu X, Brüggemann N, Zheng X, Han X, Dittert K, Butterbach-Bahl $\mathrm{K}$ (2011) Feedback of grazing on gross rates of $\mathrm{N}$ mineralization and inorganic N partitioning in steppe soils of Inner Mongolia. Plant Soil 340:127-139. https://doi.org/10.1007 /s11104-010-0575-z

Yoshinari T, Knowles R (1976) Acetylene inhibition of nitrous oxide reduction by denitrifying bacteria. Biochem Biophys Res Commun 69:705-710. https://doi.org/10.1016/0006-291 X(76)90932-3

Publisher's Note Springer Nature remains neutral with regard to jurisdictional claims in published maps and institutional affiliations. 